\title{
LA DIFERENCIA EN LA IGUALDAD. EL DESAFÍO JUDICIAL PARA LA INCLUSIÓN DE LAS COMUNIDADES ABORÍGENES EN UN MUNDO PLURICULTURAL
}

\begin{abstract}
Natalia Patricia COPELlO BARONE
RESUMEN: El artículo recuerda que los pueblos indígenas son sujetos del derecho internacional; por ello, en el ámbito de las Naciones Unidas y de la Organización Internacional del Trabajo, se debe fortalecer el principio de la universalidad e indivisibilidad de los derechos humanos, así como su aplicación a todos los individuos reconocidos internacionalmente. Se afirma que los pueblos indígenas de las Américas constituyen un segmento organizado, distintivo e integral de su población y tienen derecho a ser parte de la identidad nacional de los países, con un papel especial en el fortalecimiento de las instituciones del Estado y en la realización de la unidad nacional basada en principios democráticos; además, algunas de las concepciones e instituciones democráticas consagradas en las Constituciones de los Estados americanos tienen origen en instituciones de los pueblos indígenas, y muchos de sus actuales sistemas participativos de decisión y de autoridad contribuyen al perfeccionamiento de las democracias en las Américas. Por todo ello es urgente el desarrollo crítico y reflexivo de la evolución en la concepción de pluriculturalidad, la cual contribuirá al desarrollo de un marco jurídico modelo que se ha vislumbrado en distintos países como Ecuador y Guatemala.

Palabras clave: Derechos humanos, multiculturalismo, comunidades aborígenes, inclusión, ejercicio efectivo de los derechos humanos.

ABSTRACT: Both in the International System for Human Rights and in the Latin American Human Rights System, devices numerous international instruments have highlighted the important role that institutional lies with the courtsnational and supra-as guarantors of the effective exercise of human rights, to enshrine the right of access to justice and provide an effective remedy before any violations of such rights, arising from acts or omissions of States or individuals, which also requires courts to have impartial and independent. It is important significance to ask questions about this matter relating to the validity of these rights from various Aboriginal communities and also the actual knowledge by the courts about multiculturalism and its evolution. The analysis of this article coadyuda critical to development and reflective of the evolution in the concept of multiculturalism, which is of paramount importance since it will contribute to developing a legal framework that embraces both systems, model that has been glimpsed in different countries such as Ecuador and Guatemala, giving assurances, and that through the inclusion will be achieved consensus among those who are not forced to delay their own values, and hence are enforcing best way to hold the Rights.

Descriptors: Human Rights, Multiculturalism, Aboriginal Communities, Inclusion, Effective Exercise of Human Rights.
\end{abstract}

Fecha de recepción: 30 de enero de 2008.

Fecha de dictamen: 11 de diciembre de 2008. 


\section{INTRODUCCIÓN}

Ya en las postrimerías del siglo XX señalaba Bobbio que los derechos humanos nos exigían ocuparnos de discutir - antes que de su fundamentación filosófica - acerca de las mejores maneras de lograr que éstos adquieran vigencia efectiva para todos los pueblos del orbe, ${ }^{1}$ este desafío subsiste en la posmodernidad y nos obliga a reflexionar sobre los mecanismos más adecuados y eficaces para asegurar el ejercicio efectivo de tales derechos.

Precisamente, sobre este aspecto, tanto en el sistema internacional de derechos humanos como en el sistema latinoamericano de derechos humanos, numerosos dispositivos de los instrumentos internacionales han destacado el trascendente rol institucional que corresponde a los órganos jurisdiccionales —nacionales y supranacionales - como garantes del ejercicio efectivo de los derechos humanos, ${ }^{2}$ al consagrar el derecho al acceso a la justicia y a disponer de un recurso judicial efectivo ante eventuales violaciones de tales derechos, derivadas de acciones u omisiones de los propios Estados o de los particulares, lo que requiere además disponer de tribunales imparciales e independientes. ${ }^{3}$

1 Señalaba el filósofo italiano que "...respecto de los derechos del hombre el problema grave de nuestro tiempo era no el de fundamentarlos sino el de protegerlos...", agregando más adelante que “...el problema al que nos enfrentamos, en efecto, no es filosófico sino jurídico y, en un sentido más amplio, político. No se trata tanto de saber cuáles y cuántos son esos derechos, cuál es su naturaleza y fundamento, si son derechos naturales o históricos, absolutos o relativos, sino cuál es el modo más seguro para garantizarlos, para impedir que pese a las declaraciones solemnes resulten continuamente violados", Bobbio, Norberto, El problema de la guerra y las vías de la paz, trad. de Jorge Binaghi, Barcelona, Altaya, 1998, pp. 129 y ss.

2 En este sentido, destacando este rol de los tribunales en un Estado constitucional de derecho, se ha sostenido desde la doctrina especializada que "...la incorporación de los derechos fundamentales en el nivel constitucional, cambia la relación entre el juez y la ley y asigna a la jurisdicción una función de garantía del ciudadano frente a las violaciones de cualquier nivel de la legalidad por parte de los poderes públicos", Ferrajoli, Luigi, Derechos y garantías. La ley del más débil, trad. de Perfecto A. Ibáñez, Madrid, Trotta, 2004, pp. 26 y ss.

3 En efecto, así se desprende de los artículos 8o. y 10 de la Declaración Universal de Derechos Humanos; del artículo 2o., apdos. 3, inc. a), artículo 9o., apdos. 3 y 4, y artículo 14 del Pacto Internacional de Derechos Civiles y Políticos; del artículo 18 de la Declaración Americana de los Derechos y Deberes del Hombre; y de los artículos 8o. y 25 de la Convención Americana sobre Derechos Humanos, entre otros. 
La tutela de tales derechos en los Estados latinoamericanos resulta condicionada, muchas veces, por la disponibilidad de remedios procesales ágiles y eficaces ante su violación, por diversos obstáculos para el acceso a la justicia, pero - fundamentalmente- por el grado de imparcialidad e independencia de los tribunales nacionales, y por su grado de compromiso con los valores resguardados por los citados derechos.

Por otra parte, la existencia de numerosas comunidades aborígenes en Argentina y en muchos de los Estados que integran el subcontinente latinoamericano ha determinado que los derechos de tales comunidades - y de sus miembros - hayan sido expresamente reconocidos con diversa amplitud en sus Constituciones políticas, las que resultan complementadas por algunos instrumentos internacionales de derechos humanos que se han ocupado de desarrollar específicamente los contenidos y límites de tales derechos.

No obstante ello, el pleno ejercicio de los derechos de las comunidades aborígenes latinoamericanas, dista mucho de ser una realidad, por cuanto las alarmantes violaciones de los mismos por parte de algunos Estados nos exigen buscar los mecanismos más adecuados y eficaces para asegurar su goce efectivo.

Asumiendo el desafío que nos plantea Bobbio, en el presente trabajo nos proponemos efectuar un análisis crítico del accionar de los órganos jurisdiccionales, al resolver controversias en las que están comprometidos los derechos de las comunidades aborígenes.

Hemos escogido ocuparnos de tales derechos porque consideramos sumamente pertinente compartir nuestras reflexiones junto a otros estudiantes de derecho sobre una problemática común a la mayoría de los Estados latinoamericanos, que refleja además un aspecto distintivo y particular de la realidad de nuestro subcontinente.

A los efectos de delimitar nuestro universo de análisis, concentraremos nuestra atención en los más recientes pronunciamientos sobre tales controversias, emitidos por la Corte Interamericana de Derechos Humanos (en adelante, $\mathrm{CIDH}$ ) - en ejercicio de su jurisdicción contenciosa-, y por la Corte Suprema de Justicia de la Nación argentina (en adelante, CSJN), y por los restantes tribunales argentinos de diversas instancias. ${ }^{4}$

4 Para el análisis de los precedentes jurisprudenciales argentinos, hemos seleccionado los emitidos luego de la reforma constitucional de 1994, mediante la que se introdujo el artículo 75, inc. 17 en la Constitución argentina, lo que importó una sustancial modifi- 
En igual sentido, identificaremos previamente diversas variables que se manifiestan de modo particular en la problemática aborigen, y que definen los rasgos de los derechos de estas comunidades, así como su extensión, sus límites y la legitimación para su ejercicio.

Entre tales variables consideraremos cuál ha sido el derecho aplicado para la solución del caso, derecho positivo o derecho consuetudinario de la comunidad, y — en su caso - si se ha determinado algún límite a este último; si se ha considerado al colectivo de aborígenes como un pueblo, comunidad o minoría; si se han empleado criterios de inclusión o exclusión de los miembros de tal colectivo en el acceso a la justicia, ya sea, mediante la exigencia de un riguroso cumplimiento de las formalidades procesales, o mediante otros criterios restrictivos; y si se ha dispensado a tales miembros un trato igualitario o discriminatorio.

También consideraremos si el proceder de los tribunales responde a un paradigma de sociedad multiétnica y pluricultural, tributario del respeto a las diferencias, o a un paradigma de homogeneidad social, que responde a una política de asimilación coactiva y de avasallamiento de las diferencias, teniendo en cuenta además los derechos en conflicto en cada una de las controversias.

Conforme al enfoque que nos hemos propuesto, el empleo de tales variables, y su modo de incidencia en los fallos analizados, nos permitirá determinar qué rasgos caracterizan la labor judicial de la CIDH, de la CSJN, y de los tribunales provinciales argentinos, particularmente de qué modo han sido considerados los derechos humanos de los aborígenes ante tales órganos jurisdiccionales, y la tutela que han encontrado en los estrados judiciales.

\section{LA PROBLEMÁTICA ACTUAL DE LOS PUEBLOS ABORÍGENES}

La realidad de los pueblos aborígenes puede ser mirada de muchas maneras. Las Constituciones latinoamericanas no han sido indiferentes hacia ellos, así vemos que muchas de ellas dieron un vuelco y hoy consagran sus derechos. ${ }^{5}$

cación del tratamiento constitucional de la cuestión, con respecto al texto anterior, artículo 67 , inc. 15 .

5 En las Constituciones latinoamericanas podemos observar la consagración de los derechos de los pueblos indígenas: 
Los pueblos aborígenes "tienen una cosmovisión propia del mundo, basada en una relación filial con la madre naturaleza... la esencia de nuestra identidad, se da alrededor de la misma".6 "Mientras que los pueblos indígenas se consideran parte de la naturaleza, otras culturas consideran que el hombre es el centro y que la naturaleza debe servir al hombre, y estar al servicio del hombre".?

En el Primer Seminario de Políticas Sociales para los Pueblos Indígenas de Argentina, con concurrencia de representantes de las comunidades indígenas Kolla, Mapuche, Tehuelche, Huarpe, Ranquel, Mocoví, Toba, Pilagá, Wichi, Diaguito - Calchaquí, Pumarca, Ava - Guaraní, Omaguacas, Atacama, Cochinocas, Ochorza y otros se afirmó: "Que la principal responsable de la pobreza de los pueblos indígenas argentinos es la pérdida de sus tierras y territorios, por eso, para luchar contra la pobreza estiman esencial que los pueblos indígenas tengan la propiedad comunitaria de las tierras". ${ }^{8}$

Constitución Nacional de la República Argentina de 1853-1860 y sus reformas de 1994: artículo 75 inc. 17 (preexistencia étnica y cultural, identidad, educación bilingüe e intercultural, personería jurídica, tierras comunitarias, desarrollo humano, participación en la gestión, poderes concurrentes);

Constitución Política del Estado de Bolivia 1966-1967 y sus reformas: artículo 171 (tierras comunitarias, identidad, lenguas, costumbres, instituciones, personería jurídica, derecho consuetudinario con limite constitucional);

Constitución Política de Colombia, de 1991 y sus reformas: artículo 7o. (diversidad étnica y cultural), artículo 8o. (protección de riquezas naturales y culturales), artículo 10 (idioma);

Constitución Política de la República del Ecuador, de 1979 y sus reformas: artículo 4o. (condena colonialismo, neocolonialismo y de discriminación o segregación racial, derecho a liberarse de lo condenado en el mismo artículo), artículo 110 (defensores públicos para indigenas);

Constitución Política de la República de Guatemala, de 1985 y sus modificatorias: artículo 57 (Derecho a la cultura), Artículo 58 (Identidad cultural), Artículo 66 (Protección a grupos étnicos), artículo 67 (Protección a las tierras y las cooperativas agrícolas indígenas), Artículo 68 (Tierras para comunidades indígenas), Artículo 143 (Idioma oficial).

6 Figueroa, Viviana Elsa, "Ambiente, derechos humanos y comunidades indígenas", Derechos humanos y ambiente en la República argentina. Propuestas para una agenda nacional, Córdoba, Centro de Derechos Humanos y Ambiente, 2005, p. 115.

7 Ibidem, p. 116.

8 Robledo, Federico Justiniano, "La necesidad de humanizar la legislación de protección a nuestros pueblos indígenas", Revista Debates de Actualidad de la Asociación 
"Actualmente es lamentable que cada uno de los pueblos indígenas continúe enfrentando y resistiéndose a problemas cada vez más críticos, al punto de que muchos de ellos están amenazados gravemente de sufrir su extinción cultural (etnocidio) e inclusive físico (genocidio)". ${ }^{9}$ En este mismo sentido, Rigoberta Menchú Tum, ${ }^{10}$ Premio Nobel de la Paz (1992), indígena guatemalteca, denuncia los genocidios cometidos contra los pueblos indígenas de todo el mundo. ${ }^{11}$

La Iglesia Católica Apostólica Romana ha dicho: "Una cultura nacional no implica una identidad uniforme. La nación puede congregar, en torno a un núcleo de valores básicamente común, diversas regiones culturales, que tienen su propia característica particular. Variedad ésta que no daña sino que enriquece a la cultura común". ${ }^{12}$

"Ante esta compleja realidad, surge hoy más que nunca el imperioso deber por parte del Estado y de la sociedad civil de asumir responsablemente un nuevo proceso de interrelación con los pueblos indígenas y establecer un diálogo intercultural basado en el respeto mutuo". 13

\section{LAS VARIABLES QUE CONSIDERAMOS PARA ANALIZAR LA JURISPRUDENCIA}

Juan Bautista Alberdi aconsejó: "Cread la jurisprudencia, que es el suplemento de la legislación, siempre incompleta, y dejad en reposo las leyes, que de otro modo jamás echarán raíz". ${ }^{14} \mathrm{Y}$ entendió que

Argentina de Derecho Constitucional, año XX, núm. 195, mayo-noviembre de 2005, Santa Fe, República Argentina, 27 de octubre de 2005, p. 24.

9 Robledo, Federico Justiniano, "La necesidad de humanizar la legislación de protección a nuestros pueblos indígenas", Revista Debates de Actualidad de la Asociación Argentina de Derecho Constitucional, cit., nota 8, p. 24.

10 Figueroa, Viviana Elsa, op. cit., nota 6, p. 132.

11 Cfr. Menchú Tum, Rigoberta, "Los derechos de los indígenas: Rigoberta Menchú Tum y síntesis de su entrevista con Guianni Miná”, en la ocasión del Foro de Porto Alegre 2002, "Un Mundo Mejor es Posible", Le Monde Diplomatic, Sperling \& Kupfer, 2002, p. 115.

12 Iglesia y Comunidad Nacional, XLII Asamblea Plenaria, del 4 al 9 de mayo de 1981, Conferencia Episcopal Argentina, Oficina de Libro, República Argentina, 1990, p. 30 .

13 Robledo, Federico Justiniano, op. cit., nota 8, p. 28.

14 Figueroa, Viviana Elsa, op. cit., nota 6, p. 126. 
La interpretación, el comentario, la jurisprudencia, es el gran medio de remediar los defectos de las leyes... La ley es un Dios mudo: habla siempre por la boca del magistrado. Éste la hace ser sabia o inicua. De palabras se compone la ley, y de palabras se ha dicho que no hay ninguna mala, sino mal tomada. ${ }^{15}$

A la luz de estas sabias palabras, analizamos distintos casos jurisprudenciales. Todos ellos diversos y nutridos de fundamentos que ilustran o no, el camino a seguir de aquí en adelante con respecto a la tutela judicial de los derechos de los pueblos indígenas.

\section{Diferencia conceptual entre pueblo y comunidad indigena}

Ahora conviene diferencia dos nociones: pueblo y comunidad. "Pueblo o nación aborigen es el conjunto de familias socialmente organizadas, con un origen cultural común, cuya evolución y desenvolvimiento viene dándose en un territorio desde la época anterior a la Constitución del Estado nacional. Algunos lo identifican como etnias". ${ }^{16}$ "Comunidades indigenas son el conjunto de familias socialmente organizadas con un origen cultural común que integran un pueblo indígena del que forman parte". ${ }^{17}$

Podemos concluir que "entre pueblo indígena y comunidades indígenas hay una relación de género a especie". ${ }^{18}$ Así, pueden haber muchas comunidades en un pueblo.

\section{Multiculturalidad, pluriculturalidad e interculturalidad- homogeneidad social}

Cultura, ${ }^{19}$ en palabras de Martínez Paz, es "la expresión de una particularidad histórica, una manera de mirar y construir el mundo y una matriz

15 Alberdi, Juan Bautista, Bases y puntos de partida para la organización política de la República Argentina, derivados de la Ley que preside al desarrollo de la civilización en la América del Sur", Córdoba, República de Argentina, Academia Nacional de Derecho y Ciencias Sociales de Córdoba, 2002, p. 185.

16 Figueroa, Viviana Elsa, op. cit., nota 6, p. 130.

17 Ibidem, p. 131.

18 Idem.

19 Cançado Trindade, António Augusto, entiende que "El concepto de cultura —originado del 'colere' romano, significando cultivar, tomar en cuenta, cuidar y preservar-, se 
de vida dotada de sentido". ${ }^{20}$ En estas tres palabras resulta un denominador común, por lo que señalamos las diferencias entre los prefijos: al decir "multi" se hace referencia a varias, muchas, más de dos culturas al menos; al decir "pluri" se refiere a una culturas plurales, y lo plural en contraposición de lo singular, está compuesto por más de dos culturas al menos (igual que con el prefijo "multi"); en cambio, cuando hablamos en términos de "inter" lo hacemos para referir "entre" culturas, vale aclarar que cuando se da ese inter se debe hacer con respeto para no avasallar ninguno de los dos extremos. "La interculturalidad constituye por excelencia preponderantemente el principio de la «diversidad cultural»". 21

\section{Exclusión e inclusión}

La exclusión, como participación, reviste múltiples facetas, pudiendo concretarse en la falta de acceso a bienes y servicios públicos como privados; a los mercados de trabajo; a la protección de condiciones satisfactorias en el empleo; a la tierra y otros bienes de producción y a gran número de derechos humanos, entre ellos los de organización, seguridad, dignidad e identidad. La exclusión comprende la mayoría de los aspectos de la pobreza, pero también implica cuestiones más amplias de participación en la sociedad y en el desarrollo. ${ }^{22}$

La inclusión sería la otra cara de la moneda y se da brindando un acceso a la educación bilingüe y que respete su identidad, con el acceso a la justicia en una tutela efectiva e igualdad de oportunidades real y no sólo formal. Vale aclarar que la inclusión y la exclusión pueden tener distintos matices: social, política, ${ }^{23}$ económica, cultural, etcétera.

manifestó, originalmente, en la agricultura (el cuidado con la tierra)", Corte IDH, Caso Comunidad Indígena Sawhoyamaxa vs. Paraguay, sentencia del 29 de marzo de 2006, serie C, núm. 146, en su voto particular, considerando núm. 4. Cfr. Http://www.cor teidh.or.cr/docs/casos/votos/vsc_cancado_146_esp2.doc.

20 Martínez Paz, Fernando, El mundo jurídico multidimensional, Córdoba, Advocatus, 1996, p. 16.

21 Robledo, Federico Justiniano, op. cit., nota 8, p. 28.

22 Consejo de Juventud de España, Exclusión social: una realidad a superar, Madrid, España, Consejo de Juventud de España, 2003, pp. 7 y 8.

23 Caso Yatama vs. Nicaragua, sentencia del 23 de junio de 2005.

El 17 de junio de 2003, la Comisión Interamericana de Derechos Humanos sometió ante la Corte una demanda contra el Estado de Nicaragua la cual se originó en la de- 


\section{Minoría}

Minoría es mucho más que un grupo numéricamente minoritario; ${ }^{24}$ es una colectividad humana, que se encuentra en situación de dependencia o subordi-

nuncia recibida en la Secretaría de la Comisión el 26 de abril de 2001. La Comisión presentó la demanda con el fin de que la Corte decidiera si el Estado violó los artículos 80., 25 y 23 (derechos políticos) de CADH, todos ellos en relación con los artículos 1.1 y 2 de dicho tratado, en perjuicio de los candidatos a alcaldes, vicealcaldes y concejales presentados por el partido político regional indígena Yapti Tasba Masraka Nanih Asla Takanka (en adelante "Yatama"). Según lo alegado por la Comisión, dichas personas fueron excluidas de participar en las elecciones municipales realizadas el 5 de noviembre de 2000 en las Regiones Autónomas del Atlántico Norte y del Atlántico Sur (en adelante la "RAAN" y la "RAAS"), como consecuencia de la resolución emitida el 15 de agosto de 2000 por el Consejo Supremo Electoral. En la demanda se indicó que las presuntas víctimas presentaron diversos recursos contra dicha resolución y, finalmente, el 25 de octubre de 2000 la Corte Suprema de Justicia de Nicaragua declaró improcedente un recurso de amparo interpuesto por éstos ( $c f r$. considerandos 1 a 3). La Corte Interamericana resolvió al respecto:

“2. El Estado violó el derecho a las garantías judiciales consagrado en el artículo 8.1 de la Convención Americana sobre Derechos Humanos, en relación con el artículo 1.1 de la misma, en perjuicio de los candidatos propuestos por Yatama para participar en las elecciones municipales de 2000, en los términos de los párrafos 147 a 164 de la presente sentencia.

"3. El Estado violó el derecho a la protección judicial consagrado en el artículo 25.1 de la Convención Americana sobre Derechos Humanos, en relación con los artículos 1.1 y 2 de la misma, en perjuicio de los candidatos propuestos por Yatama para participar en las elecciones municipales de 2000, en los términos de los párrafos 165 a 176 de la presente sentencia.

”4. El Estado violó los derechos políticos y el derecho a la igualdad ante la ley consagrados en los artículos 23 y 24 de la Convención Americana sobre Derechos Humanos, en relación con los artículos 1.1 y 2 de la misma, en perjuicio de los candidatos propuestos por Yatama para participar en las elecciones municipales de 2000, en los términos de los párrafos 201 a 229 de la presente sentencia". Corte IDH, Caso Yatama vs. Nicaragua, sentencia de 23 de junio de 2005, serie C núm. 127, http://www.corteidh. or.cr/docs/casos/articulos/seriec_127_esp.pdf.

24 Para algunos autores el elemento cuantitativo es accesorio. La ONU admite inclusive, la posibilidad de "mayorías en situación minoritaria": "durante el régimen comunista la población cristiana fue numéricamente mayoritaria, aun cuando pudiere calificarse de minoría; y, sin duda, bajo el régimen de apartheid en Sudáfrica, la mayoría negra fue también una minoría". De "mayorías minoritarias" habla J. de Lucas, citado por Sanchís, Luis Pietro, "Igualdad y minorías", Derechos y Libertades. Revista del Instituto Bartolomé de las Casas, Madrid, núm. 5, año II, 1995, p. 121. 
nación, ${ }^{25}$ en la que coexisten elementos de carácter objetivo (religión, lengua, etnia, etcétera) como así también de corte subjetivo (sentimiento de pertenencia a un grupo y conciencia de alteridad o diferenciación). Puede una agrupación tener rasgos culturales diferentes a los de la mayoría de la población, pero no podrá ser considerada minoría si sus integrantes no se reconocen como tal, no tienen voluntad de ser un grupo diferenciado con identidad propia. ${ }^{26}$ Con el mismo criterio debe decirse, que no basta la subjetividad, no hay minoría sin rasgos culturales distintivos. ${ }^{27}$

"El tipo ideal de 'minoría' es un grupo que ha sido objeto de exclusión o discriminación por parte del Estado o sus ciudadanos a causa de sus características étnicas, nacionales, raciales, religiosas o lingüísticas o de su linaje". ${ }^{28}$

\section{Derecho consuetudinario de los pueblos indigenas:} aplicable o no; con o sin límites

Algunas Constituciones latinoamericanas consideran aplicable el derecho consuetudinario de los pueblos indígenas, y otras no. Entre las que lo permiten también hay que aclarar si tienen o no límites, así algunas marcan como límite la Constitución de ese Estado, en tanto si no lo hizo pue-

25 Si no hay subordinación o dependencia la situación en la que se encuentra la minoría no podrá reputarse minoritaria. Por ejemplo: la situación de la minoría blanca durante el apartheid de Sudáfrica.

26 El elemento subjetivo es un factor que determina que la existencia de las minorías sea una cuestión dinámica. La voluntad de ser diferente no es una decisión invariable ni perpetua, debe reafirmarse día a día. Muchas agrupaciones minoritarias, propietarias de una cultura propia, optan por la asimilación con sociedad mayoritaria, lo cual produce, al decir de García Canclini, las denominadas "culturas híbridas".

27 Robledo, Federico, "Derecho de las minorías en un mundo multicultural y globalizado", Globalización, democracia y paz. La visión de los jóvenes, ensayo distinguido en el Concurso Literario Interno de la Organización Argentina de Jóvenes para las Naciones Unidas, Córdoba, República Argentina, OAJNU, 2005, pp. 95 y 96.

28 Daes, Erika Irene, E/CN.4/Sub.2/2000/10, Naciones Unidas, Consejo Económico y Social, Comisión de Derechos Humanos, subcomisión de Promoción y Protección de los Derechos Humanos 520. periodo de sesiones, tema 8 del programa provisional - prevención de la discriminación y protección a las minorías - "Documento de trabajo sobre la relación y las diferencias entre los derechos de las personas pertenecientes a minorías y los derechos de los pueblos indígenas", 19 de julio de 2000, punto 48 . 
de entenderse que tienen como límite la Convención Americana de Derechos Humanos.

\section{Pluralismo o asimilación cultural}

Martínez Paz define al pluralismo como un "sistema que abre las posibilidades para el desarrollo de los modos de ser, de actuar y de pensar de cada persona, sin ahogar la diversidad". ${ }^{29}$

Pluralismo puede definirse como reconocimiento, protección y promoción de y respeto por la diversidad. El pluralismo expresa en su sentido más profundo tanto el reconocimiento como la protección a las especificidades étnica, cultural o espiritual y la aceptación de esos valores que, en una sociedad dada, alcanzan y trascienden esas especificidades. En este sentido, luego, el pluralismo es el valor operativo en la dialéctica unidad/diversidad que ofrece la base más firme para la estabilidad y la armonía en una sociedad multicultur ral. $^{30}$

La asimilación cultural sería, en contraposición del pluralismo no respetar las características culturales, ni su identidad. Así, Federico J. Robledo nos dice "Los últimos cuarenta años se caracterizaron, por una constante superación de la muy antigua tradición indigenista, que sólo intentaba su integración a la sociedad nacional, prescindiendo de la personalidad propia de los pueblos indígenas". ${ }^{31}$

29 Martínez Paz, Fernando, El mundo jurídico multidimensional, Córdoba, República Argentina, Advocatus, 1996, p. 23.

30 Diéne, Doudou, "Eliminating racism in a changing world: arguments for a new strategy", Anti-Discrimination, vol. 1, p. 16. Traducido a partir de: "It's possible to define pluralism as recognition, protection, promotion of and respect for diversity. Pluralism expresses in its profoundest sense both the recognition and protection afforde to ethni, cultural or spiritual specificities, and the acceptance of those values wich, $\mathrm{n}$ a given society, reachi out beyond and transcend those specificities. In this sense, then, pluralism is the operartive value in the unity/diversity dialectic that offers the firmest base for stability and harmony in multicultural society".

31 Robledo, Federico Justiniano, Bases constitucionales del proceso. ¿Se asegura la independencia del Poder Judicial desde la óptica de las garantías constitucionales del debido proceso y de la defensa a través de los nuevos órganos de control: el Defensor del Pueblo?, Córdoba, República Argentina, tesis doctoral en la UNC, 2006, t. I, p. 128. 
Los indígenas deben "integrarse" a la sociedad en igualdad de condiciones que el resto de la población. Explícita o implícitamente la clase política considera que es necesario "chilenizar" a las poblaciones indígenas e impedir que se perfilen con sus propias particularidades... Es por ello que predomina en la clase política un ambiente "asimilacionista" no superado. Cada vez que se proponen formas de relaciones interétnicas modernas, basadas en el reconocimiento mutuo, se producen las mismas reacciones $i$ a caso no somos todos chilenos?... A partir de esta mirada que no reconoce "al otro" se abre un escenario propicio para que vuelven todos los estereotipos y se juegue en un campo cada vez más fantasmagórico... ${ }^{32}$

\section{Discriminación o igualdad}

Discriminar es un vocablo castellano que en su raíz latina significa diferenciar. Diferencia e igualdad son dos caras de una misma moneda. La noción romana de tratar "igual entre los iguales" es hoy por consenso mayoritario completada con la de tratar "diferente a los diferentes" (para que de este modo puedan ser iguales). La jurisprudencia y doctrina abundan en este tema; cabe ahora preguntarnos, tomando como punto de referencia a nuestro mundo globalizado de culturas híbridas por qué estamos separados a pesar de nuestras semejanzas y no unidos a pesar de nuestras diferencias. "El no reconocimiento es el primer paso de la discriminación, en todo orden de las cosas. El no reconocimiento es una negación de la existencia o de su densidad". 33

\section{ANÁLISIS DE LA JURISPRUDENCIA DE LA CORTE INTERAMERICANA DE DERECHOS HUMANOS}

En el presente trabajo analizaremos dos fallos de la CIDH, a saber:

1. Caso de la Comunidad Mayagna (Sumo) Awas Tingni vs. Nicaragua, sentencia del 31 de agosto de 2001.

32 Bengolea, José, "Indígenas, institucionalidad y relaciones interétnicas en Chile", Política y sociedad en Chile. Antiguas y nuevas caras, Santiago de Chile, Hidalgo Paulo, 2005, pp. 144 y 146.

33 Ibidem, p. 145. 
2. Caso de la Comunidad Moiwana vs. Suriname, sentencia de 15 de junio de 2005.

La CIDH es un organismo jurisdiccional que cumple dos tipos de funciones: una contenciosa y otra de naturaleza consultiva. La jurisprudencia que analizaremos en este trabajo se vincula con la primera de dichas funciones. La función contenciosa es de tipo eminentemente jurisdiccional. Requiere que algún Estado parte o que la Comisión formule la respectiva demanda para posibilitar la intervención de la $\mathrm{CIDH}$, que resolverá el pleito a través de una sentencia que produce efectos de cosa juzgada. ${ }^{34}$

En estos casos se debate ante la CIDH la afectación de derechos de distintas comunidades indígenas en relación con las obligaciones generales de los Estados (artículos 1.1 y 1.2 de la CADH), la protección judicial de los derechos (artículos 8o. y $25 \mathrm{CADH}$ ) y la propiedad privada (artículo $21 \mathrm{CADH})$.

En la jurisprudencia que analizaremos, la CIDH efectúa una interpretación creativa y precisa del derecho internacional, sentando una serie de pautas y directrices de incalculable valor en materia de reconocimiento y tutela de derechos fundamentales de las comunidades aborígenes de América; que no sólo se erigen en criterios protectores de tales derechos, sino también en principios rectores que deben guiar el accionar judicial cotidiano de los tribunales nacionales.

$\mathrm{Al}$ respecto, cabe destacar que nuestra CSJN ha reconocido en numerosos precedentes ${ }^{35}$ el valor que poseen los pronunciamientos de la CIDH en materia de interpretación de los dispositivos contenidos en la $\mathrm{CADH}$.

34 Hitters, Juan Carlos, "La jurisprudencia de la Corte Interamericana como guía para la interpretación de la Constitución (El Pacto de San José de Costa Rica, en la postura de la Corte Suprema Nacional)", El Derecho, 1995, t. 164, p. 1238.

35 Así, por ejemplo en Fallos 310:518, 311:2497, 318:514, 319:1840, 321:3555, 323:4130, como también en la causa Espósito, Miguel A., del 23 de diciembre de 2004. 
1. Caso de la Comunidad Mayagna (Sumo) Awas Tingni vs. Nicaragua, sentencia de 31 de agosto de 2001

\section{A. Planteo del caso}

La CIDH tuvo oportunidad de expedirse sobre el derecho de propiedad comunitaria de los indígenas en el Caso de la Comunidad Mayagna (Sumo) Awas Tingni vs. Nicaragua. La comunidad de Awas Tingni es una comunidad indígena conformada por más de 600 personas perteneciente a la etnia Mayagna o Sumo, que habita en la Costa Atlántica de Nicaragua (Región Autónoma Atlántico Norte, en adelante RAAN).

El 2 de octubre de 1995, el síndico de la comunidad Awas Tingni presentó una denuncia ante la Secretaría de la Comisión Interamericana de Derechos Humanos, en virtud de la concesión que el Estado nicaragüense otorgó - sin intervención alguna de la Comunidad Awas Tingni- a la empresa Sol del Caribe S. A. ("Solcarsa"), para realizar explotación forestal en tierras indígenas.

La comunidad Awas Tingni emprendió diversas gestiones ante autoridades nicaragüenses con el objetivo salvaguardar su derecho sobre sus tierras. La única resolución que logró obtener favorable a su planteo fue la sentencia del 27 de febrero de 1997 de la Sala de lo Constitucional de la Corte Suprema de Justicia de Nicaragua, que resolvió el recurso de amparo interpuesto por miembros del Consejo Regional de la Región Autónoma Atlántico Norte (RAAN), declarando la inconstitucionalidad de la concesión otorgada a Solcarsa, en virtud de que la misma no había sido aprobada por el Consejo Regional de la RAAN. Pese a dicha disposición, el Estado nicaragüense no dispuso la ejecución de la resolución jurisdiccional.

La Comisión Interamericana de Derechos Humanos decidió promover la demanda contra el Estado de Nicaragua el 4 de junio de 1998. La Corte Interamericana resolvió la controversia a favor del reclamo de la comunidad Awas Tingni, declarando que el Estado de Nicaragua violó principalmente el derecho a la protección judicial consagrado en el artículo 25 y el derecho a la propiedad consagrado en el artículo 21, ambos de la Convención Americana sobre Derechos Humanos, en perjuicio de los miembros de la Comunidad Mayagna (Sumo) Awas Tingni. 


\section{B. Consideraciones vertidas por la Corte Interamericana}

La Corte Interamericana de Derechos Humanos ha establecido en el fallo objeto de examen su posición respecto a diversas cuestiones vinculadas con los derechos de los pueblos indígenas. En primer lugar, es menester destacar la trascendencia que la Corte ha otorgado al valor que tiene la tierra para las comunidades indígenas. Al respecto, ha señalado

la importancia vital que reviste la relación de los miembros de la comunidad con las tierras que ocupan, no sólo para su propia subsistencia, sino además para su desarrollo familiar, cultural y religioso. De ahí su caracterización del territorio como sagrado, por cobijar no sólo los miembros vivos de la comunidad, sino también los restos mortales de sus antepasados, así como sus divinidades. ${ }^{36}$

En las comunidades indígenas, la pertenencia de la tierra

no se centra en un individuo sino en el grupo y su comunidad... [L]a estrecha relación que los indígenas mantienen con la tierra debe de ser reconocida y comprendida como la base fundamental de sus culturas, su vida espiritual, su integridad y su supervivencia económica. Para las comunidades indígenas la relación con la tierra no es meramente una cuestión de posesión y producción sino un elemento material y espiritual del que deben gozar plenamente, inclusive para preservar su legado cultural y transmitirlo a las generaciones futuras. ${ }^{37}$

Es lo que algunos de los jueces de la Corte denominan - en su voto razonado- la dimensión intertemporal. ${ }^{38}$ Ello nos conduce al concepto

36 Corte IDH, Caso de la Comunidad Mayagna (Sumo) Awas Tingni vs. Nicaragua, sentencia del 31 de octubre de 2001, disponible en http://www.corteidh.or.cr/docs/ca sos/articulos/Seriec_79_esp.pdf, accedido el 3 de septiembre de 2006, voto razonado conjunto de los jueces A. A. Cançado Trindade, M. Pacheco Gómez y A. Abreu Burelli, considerando segundo.

37 Caso de la Comunidad Mayagna..., cit., nota anterior, párrafo 149.

38 Caso de la Comunidad Mayagna..., op. cit., nota 36, voto razonado conjunto de los jueces A. A. Cançado Trindade, M. Pacheco Gómez y A. Abreu Burelli, considerando octavo. 
de propiedad comunitaria de las tierras ${ }^{39}$ de insoslayable importancia en la temática que se analiza, que implica que "la tierra que ocupan les pertenece, a su vez ellos pertenecen a su tierra". ${ }^{40}$

La doctrina expuesta por la Corte respecto a la importancia de la tierra es concordante con el desarrollo doctrinario que de la misma se ha realizado. En este sentido, Bidart Campos ha sostenido que tanto las tierras como su uso constituyen un "espacio de radicación y de crecimiento para la integración, la cultura diferencial y la convivencia de las comunidades aborígenes". ${ }^{41}$ Por su parte, Bidegain ha señalado que el "reconocimiento de posesión de tierras tradicionalmente ocupadas está indisolublemente ligado a la permanencia de la comunidad indígena asentada, pues es una garantía de su bien común particular". ${ }^{42}$

El interrogante que surge de inmediato al introducirnos en la cuestión de las tierras de propiedad comunitaria es determinar si las mismas se encuentran reguladas por las normas del derecho civil que rigen la propiedad privada. La Corte en el fallo sub examine ha considerado la cuestión, llegando a la conclusión de que se trata de una clase de propiedad diferente, que no está alcanzada por la regulación que hace el derecho privado, la cual sólo comprende la propiedad individual. El interrogante planteado si vincula con el llamado derecho consuetudinario indígena. ${ }^{43}$

39 La propiedad comunitaria de tierras de posesión ancestral por parte de comunidades indígenas ha tenido recepción normativa en muchos países latinoamericanos. Así, por ejemplo, Nicaragua (artículos 5o., 89 y 180, Constitución Política), Argentina (artículo 75 inc. 17, Constitución Nacional), entre otros. También el Convenio 169 de la OIT se refiere a la cuestión: "los gobiernos deberán respetar la importancia especial que para las culturas y valores espirituales de los pueblos interesados reviste su relación con las tierras o territorios, o con ambos, según los casos, que ocupan o utilizan de alguna otra manera, y en particular, los aspectos colectivos de esa relación" (artículo 13.1) y "Deberá reconocerse a los pueblos interesados el derecho de propiedad y de posesión sobre las tierras que tradicionalmente ocupan" (artículo 14.1).

40 Caso de la Comunidad Mayagna..., op. cit., nota 36, voto razonado conjunto de los jueces A. A. Cançado Trindade, M. Pacheco Gómez y A. Abreu Burelli., considerando octavo.

41 Bidart Campos, Germán, Manual de la Constitución reformada, Buenos Aires, Ediar, 1999, t. III, p. 119.

42 Bidegain, Carlos María, Curso de derecho constitucional, Buenos Aires, Abeledo Perrot, 1995, t. II, p. 45.

43 "Lo que se denomina genéricamente derecho consuetudinario indígena no es un cuerpo estructurado, ni mucho menos codificado; son una serie de prácticas reales que se llevan a cabo de manera distinta en diferentes comunidades, para resolver una serie de 
La Corte trató la cuestión al analizar el régimen aplicable a la propiedad comunitaria de las tierras:

El concepto comunal de la tierra —inclusive como lugar espiritual—y sus recursos naturales forman parte de su derecho consuetudinario; su vinculación con el territorio, aunque no esté escrita, integra su vida cotidiana, y el propio derecho a la propiedad comunal posee una dimensión cultural. En suma, el habitat forma parte integrante de su cultura, transmitida de generación en generación. ${ }^{44}$

La Corte, en diversos pasajes ha reconocido expresamente el valor a la costumbre de los pueblos indígenas como fuente de derecho, constituyendo lo que se denomina derecho consuetudinario indigena, que es el que rige - en definitiva - la propiedad comunitarias de las tierras de los aborígenes, ${ }^{45}$ las que, a su vez, gozan de protección judicial en virtud de la interpretación amplia que la Corte ha efectuado del artículo 21 de la Convención Americana sobre Derechos Humanos.

En este sentido, el Tribunal sostuvo que el "derecho consuetudinario de los pueblos indígenas debe ser tenido especialmente en cuenta... la posesión de la tierra debería bastar para que las comunidades indígenas que

problemas de administración de justicia, resolución de conflictos, mantenimiento del orden interno, normatividad de los reclamos interpersonales, vinculación con el mundo exterior, etcétera. En el derecho consuetudinario, la tierra, al vincularla con los seres humanos, es vista como un lugar espiritual, puesto que cuenta con sitios sagrados, con bosque, etcétera. Esa vinculación del ser humano con el territorio no necesariamente está escrita, es algo que se vive en lo cotidiano" (peritaje de Rodolfo Stavenhagen Gruenbaum, antropólogo y sociólogo, Caso de la Comunidad Mayagna..., op. cit., nota 36).

44 Caso de la Comunidad Mayagna..., op. cit., nota 36, voto razonado conjunto de los jueces A. A. Cançado Trindade, M. Pacheco Gómez y A. Abreu Burelli, considerando sexto in fine.

45 El derecho consuetudinario indígena se caracteriza por ser un "fenómeno esencialmente dinámico, que por ello, se resiste, en principio, a ser encorsetado en categorías jurídicas preestablecidas, que operarían sin referencia al contexto social y cultural en el que éste se produce, representando una visión abstracta e incluso sesgada de la realidad social. Este carácter dinámico, esencial en el derecho consuetudinario, rechazaría entonces toda idea de positivización" (Barale, Laura et al., "Las comunidades indígenas en la Reforma Constitucional del 1994. Del Principio de Identidad a las Circunstancias de Justicia”, Semanario Jurídico. Fallos y Dotrina, Córdoba, República Argentina, núm. 1324, enero de 2001, p. 17). 
carezcan de un título real sobre la propiedad de la tierra obtengan el reconocimiento oficial de dicha propiedad y el consiguiente registro". ${ }^{46}$

El remplazo del término "propiedad privada" por el de "uso y goce de los bienes" permite sostener que la disposición no sólo protege la propiedad privada individual, sino también otras formas de propiedad, como la comunitaria de los pueblos indígenas. ${ }^{47}$

La Corte Interamericana también establece claramente su tesitura respecto a que los indígenas gozan del derecho a ser reconocidos como tales, y a que se respete y preserve su integridad cultural. De esta manera consolida la corriente que propugna eliminar las prácticas de "asimilación coactiva" de los indígenas a la vida en la "sociedad civilizada", para considerarlos miembros de una comunidad que se rige por pautas diferentes pero que deben ser respetadas. En este sentido, la Corte ha sostenido:

muchas son, en nuestros días, las sociedades multiculturales, y la atención debida a la diversidad cultural nos parece que constituye un requisito esencial para asegurar la eficacia de las normas de protección de los derechos humanos, en los planos nacional e internacional. Del mismo modo, consideramos que la invocación de las manifestaciones culturales no puede atentar contra los estándares universalmente reconocidos de observancia y respeto a los derechos fundamentales de la persona humana ${ }^{48}$ [las cursivas nos pertenecen].

La tendencia de las últimas décadas a respetar y preservar la identidad de los pueblos indígenas ha tenido no sólo recepción jurisprudencial, sino también normativa y doctrinaria. Desde el punto de vista normativo,

46 Caso de la Comunidad Mayagna..., op. cit., nota 36, párrafo 151. En este sentido nos advierte la doctrina: "El respeto que se debe a las culturas indígenas no puede llevar a su marginación de los beneficios del desarrollo, que abarcan aspectos sanitarios, educativos, de infraestructura de caminos, energía, vivienda... Además, tampoco puede admitir prácticas contrarias a los derechos humanos más elementales, aun cuando estén incorporadas a sus hábitos culturales", Bidegain, Carlos María, op. cit., nota 42, p. 37.

47 Ibidem, párrafo 145. Cabe destacar que no hay solamente una sola forma posible de usar y gozar de los bienes, sino que cada pueblo, según sus costumbres, características y creencias realizar un determinado "uso y goce de los bienes", por lo que dichos conceptos no son ajenos al ámbito histórico en el que se insertan.

48 Ibidem, voto razonado conjunto de los jueces A. A. Cançado Trindade, M. Pacheco Gómez y A. Abreu Burelli, considerando catorce. 
el reconocimiento de la identidad de los pueblos indígenas ha quedado plasmado en numerosas Constituciones a partir de las corrientes reformadoras de la década del ochenta. ${ }^{49}$ Por su parte, la doctrina latinoamericana ha bregado por la vigencia irrestricta de un verdadero pluralismo en el marco de la restauración del sistema democrático en Latinoamérica, que respete las costumbres, valores, tradiciones y particularidades propias de los distintos grupos que integran la sociedad. Así, se ha sostenido que en nuestros días existe una visión "integrativa [de los pueblos aborígenes, la sociedad] pero respetuosa de los valores propios a la identidad del indígena... coexisten dos valores de nivel equivalente: integración y protección de la identidad indígena"50 (la cursiva nos pertenece).

Por su parte, ciertos autores han señalado que

el principio de identidad de las comunidades indígenas ha ingresado [con las últimas reformas constitucionales en Latinoamérica] al elenco de derechos fundamentales que... integran el "coto vedado" de nuestro sistema jurídico, y en consecuencia, los derechos derivados de este principio constituyen "bienes básicos no negociables"; quedando garantizado de esta manera, frente al Estado y al resto de la comunidad, el respeto a las particularidades de estas minorías. Al mismo tiempo... estos derechos, no deben ser llevados al extremo de negar o menoscabar los restantes derechos fundamentales integrantes de este "coto vedado". 51

Finalmente, se ha sostenido que una

democracia de inclusión implica la adopción de un sistema político basado en el reconocimiento de la diversidad étnica y cultural; por lo mismo, la consagración de los sistemas y mecanismos de intervención, procedimientos propios y particulares de gestión de los pueblos indígenas... reconociendo sus valores y principios propios y exclusivos que no pueden ser desconocidos ni suplantados. ${ }^{52}$

49 Así, por ejemplo, lo contemplan las Constituciones de Argentina, Paraguay, Colombia, Brasil, entre otras.

50 Bidegain, Carlos María, op. cit., nota 42, p. 39.

51 Barale, Laura et al., op. cit., nota 45, p. 16.

52 Rivera, José Antonio, "Los pueblos indígenas y las comunidades campesinas en el sistema constitucional boliviano", Anuario 2005 de Derecho Constitucional Latinoamericano, Montevideo, vol. 11, 2005, t. I, p. 210. 


\section{Criterios vertidos por la Corte}

Resulta a nuestro entender loable la utilización por parte de la Corte Interamericana de las medidas para mejor proveer. Ello en virtud de que puede llegar a constituir una vía permitida para llevar adelante una discriminación inversa ante situaciones en las que las partes contendientes se encuentren en disparidad de condiciones. También consideramos plausible el criterio seguido por la Corte en cuanto a la flexibilidad y la ausencia de formalismo en la admisión y valoración de las pruebas. ${ }^{53}$

\section{Valoración crítica del caso}

El Caso de la Comunidad Mayagna (Sumo) Awas Tingni vs. Nicaragua sienta importantes precedentes en cuanto a los derechos de las comunidades aborígenes. Compartimos con el criterio señalado de reafirmar el derecho a la integridad y a la preservación de la cultura, valores, tradiciones y formas de organización de las comunidades aborígenes, aunque ello no está exento de limitaciones. También resultan atinadas las consideraciones vertidas por la Corte tendentes a garantizar dicha integridad de las comunidades indígenas, a través de la interpretación normativa que permite sostener la vigencia - como orden normativo propio- del derecho consuetudinario indígena. En este punto coincidimos también con los criterios adoptados por el tribunal, referidos a la flexibilidad y ausencia de formalismos que inspiran la admisión y la valoración de las pruebas.

Resulta sumamente desalentadora la tesitura adoptada por el Estado de Nicaragua en el fallo sub examine, ya que no ha hecho sino desconocer en forma manifiesta las prerrogativas que corresponden a las comunidades indígenas, atentando contra sus derechos fundamentales. En particular, resulta preocupante este tipo de conductas en virtud de que obstan a la "inserción real y material de estos pueblos al sistema constitucional, esto es, a la estructura social, económica y política, con el reconocimiento pleno de sus sistemas de organización social y política, con su identidad cultural, su territorio y sus costumbres y tradiciones". ${ }^{4}$

53 Caso de la Comunidad Mayagna..., op. cit., nota 36, pfo. 89.

54 Rivera, José Antonio, op. cit., nota 52, p. 202. 
Dificultades como la planteada en el párrafo precedente conducen a posiciones escépticas en cuanto a la existencia de los derechos que - si bien reconocidos normativamente- en la práctica aparecen como inexistentes. Quizás ello constituya la primera percepción que los hechos puedan generar. Pero no hay que acudir a tal punto extremo. Pensamos que a pesar de la falta de vigencia de derechos reconocidos, el reconocimiento mismo importa un avance sumamente significativo respecto de épocas pretéritas. Con ello se da inicio al proceso que debiera concluir con el ejercicio efectivo de los derechos reconocidos, en el cual -indudablemente- la voluntad política del Estado ocupa un lugar de magnitud inconmensurable. ${ }^{55}$

Por lo tanto, consideramos que si bien es valioso el reconocimiento normativo que se ha logrado de los derechos de las comunidades aborígenes, ello no resulta suficiente, ya que constituye una etapa de tránsito necesaria pero no suficiente para el goce efectivo de los derechos reconocidos, objetivo hacia el cual debemos avanzar.

2. Caso de la Comunidad Moiwana vs. Suriname, sentencia del 15 de junio de 2005

\section{A. Planteo del caso}

El presente caso de la Corte se remonta a 1986, cuando miembros de las fuerzas armadas de Suriname atacaron la comunidad N'djuka Maroon de Moiwana. Los soldados supuestamente masacraron a más de 40 hombres, mujeres y niños, y arrasaron la comunidad. La Comisión presentó la demanda ante la CIDH el 20 de diciembre de 2002. Suriname presentó una serie de excepciones de carácter procesal por entender que su país recién ratificó la Convención Americana en 1987, y los hechos se suscitaron en 1986 negando de ese modo la competencia de la Corte en este caso.

Por su parte, la Comisión reconoció que los hechos se produjeron con anterioridad y que por ende no eran competencia de la Corte. Sin embar- 
go fundó su demanda en la "presunta denegación de justicia y el desplazamiento ocurrido con posterioridad al ataque....".56

\section{B. Consideraciones vertidas por la CIDH}

En primer término, el Tribunal al referirse a si efectivamente hubo o no violación del artículo 5o. ${ }^{57}$ de la CADH que resguarda el derecho a la integridad personal, se pronunció positivamente y fundó su análisis en torno a tres ejes cardinales:

a) obstaculización a los esfuerzos de los miembros de la comunidad para obtener justicia, lo cual surge claramente de la falta de una investigación seria y completa por parte del Estado para incriminar y juzgar a los culpables. En tal sentido el órgano jurisdiccional, entendió que

tal ausencia de recursos efectivos ha sido considerada por la Corte como fuente de sufrimiento y angustia para víctimas y sus familiares; incluso, en el presente caso, ha creado en los miembros de la comunidad la convicción de que el Estado los discrimina activamente... 58

b) imposibilidad de los miembros de la comunidad de honrar apropiadamente a sus seres queridos fallecidos, lo cual la Corte lo observa como un hecho claramente contrastable en cuanto los cadáveres de los miembros asesinados no fueron devueltos e incluso algunos fueron cremados, lo cual es absolutamente contrario a las tradiciones de la comunidad Moiwana;

c) la separación de los miembros de la comunidad de sus tierras tradicionales. "Los hechos probados demuestran que la conexión de la comunidad N'djuka a su tierra tradicional reviste vital importancia espiritual,

56 Corte IDH, Caso de la Comunidad Moiwana vs. Suriname, sentencia del 15 de junio de 2005, disponible en http://www.corteidh.or.cr/docs/casos/articulos/seriec_124_ esp.pdf, párrafo 3 .

57 El artículo 5o. de la Convención Americana de Derechos Humanos reza que: 1. Toda persona tiene derecho a que se respete su integridad física, síquica y moral. 2. Nadie debe ser sometido a torturas ni a penas o tratos crueles, inhumanos o degradantes. Toda persona privada de libertad será tratada con el respeto debido a la dignidad inherente al ser humano.

58 Caso de la Comunidad Moiwana..., op. cit., nota 56, párrafo 94. 
cultural y material", 59 la cual ha sido sistemáticamente violada al ser desplazados de sus propias tierras, provocando de ese modo muchos refugiados en la Guyana Francesa.

En segundo término, y respecto a la violación del artículo $22^{60}$ de la Convención Americana que regula lo atinente al derecho de circulación y residencia, la Corte también responsabilizó y condenó por ello al Estado de Suriname por entender que éste no proveyó de libertad y seguridad necesarias para que los miembros de la comunidad Moiwana pudieran regresar a sus tierras al no proporcionarles los medios adecuados para que los responsables de la masacre fueran investigados y juzgados de acuerdo con un procedimiento eficaz que les permitiera obtener certeza para regresar tranquilos y en paz a sus respectivas tierras ancestrales. Dentro de este orden de ideas, la Corte en el presente fallo cita lo que respecto a desplazados internos expresó el representante del secretario general de las Naciones Unidas en 1998 al decir: "Los Estados tienen la obligación específica de tomar medidas de protección contra los desplazamientos de pueblos indígenas, minorías, campesinos, pastores y otros grupos que tienen una dependencia especial de su tierra o un apego particular a la misma". ${ }^{61}$

En tercer lugar, otro de los derechos en conflicto por los cuales tuvo que pronunciarse esta Corte, es el referido al derecho de propiedad, lamentablemente violado y desconocido en la mayoría de los pueblos americanos, pese a existir una fuerte normativa tanto a nivel nacional como

59 Ibidem, párrafo 101.

60 El artículo 22 de la Convención Americana establece que: 1. Toda persona que se halle legalmente en el territorio de un Estado tiene derecho a circular por el mismo y, a residir en él con sujeción a las disposiciones legales. 2. Toda persona tiene derecho a salir libremente de cualquier país, inclusive del propio. 3. El ejercicio de los derechos anteriores no puede se restringido sino en virtud de una ley, en la medida indispensable en una sociedad democrática, para prevenir infracciones penales o para proteger la seguridad nacional, la seguridad o el orden públicos, la moral o la salud públicas o los derechos y libertades de los demás. 4 . El ejercicio de los derechos reconocidos en el inciso 1 puede asimismo ser restringido por la ley, en zonas determinadas, por razones de interés público. 5. Nadie puede ser expulsado del territorio del Estado del cual es nacional, ni ser privado del derecho a ingresar en el mismo.

61 Caso de la Comunidad Moiwana..., op. cit., nota 56, párrafo 111, punto 9. 
internacional ${ }^{62}$ en pos de una protección adecuada de este derecho fundamental.

En este caso, la Corte entendió que

en el caso de comunidades indígenas que han ocupado sus tierras ancestrales de acuerdo con sus prácticas consuetudinarias - pero que carecen de un título formal de propiedad - la posesión de la tierra debería bastar para que obtengan el reconocimiento oficial de dicha propiedad y el consiguiente registro. La Corte llegó a esa conclusión considerando los lazos únicos y duraderos que unen a las comunidades indígenas con su territorio ancestral. La estrecha relación que los indígenas mantienen con la tierra debe de ser reconocida y comprendida como la base fundamental de sus culturas, su vida espiritual, su integridad y su supervivencia económica. ${ }^{63}$

En cuarto y último término, es dable referirnos respecto a las garantías judiciales y el derecho a la protección judicial, respectivamente tutelados por los artículos 8o. y 25 de la Convención Americana de Derechos Humanos. La Corte en referencia a ello ha sido contundente al expresar que Suriname sistemáticamente ha violado dichas garantías al sentenciar que no ha colocado al alcance de los miembros de la comunidad los recursos legales adecuados, simples, rápidos y eficaces, sino que por el contrario ha puesto una valla insalvable para el acceso a la justicia por parte de dicha comunidad. Asimismo, no ha respetado los plazos razonables de un debido proceso (hasta esta sentencia pasaron casi 20 años) ni ha sido efectiva la investigación llevada a cabo en relación al presente caso. En consonancia con ello, la Corte ha afirmado que

durante el proceso de investigación y el trámite judicial, las víctimas de violaciones de derechos humanos, o sus familiares, deben tener amplias oportunidades para participar y ser escuchados, tanto en el esclarecimiento de los hechos y la sanción de los responsables, como en la búsqueda de una justa compensación... ${ }^{64}$

62 El artículo 21 de la Convención Americana dispone: 1. Toda persona tiene derecho al uso y goce de sus bienes. La ley puede subordinar tal uso y goce al interés social. 2. Ninguna persona puede ser privada de sus bienes, excepto mediante el pago de una indemnización justa, por razones de utilidad pública o de interés social y en los casos y según las formas establecidas por la ley.

63 Caso de la Comunidad Moiwana..., op. cit., nota 56, pfo. 131.

64 Ibidem, pfo. 147. 
Hecho que en el caso que nos ocupa no se ha cumplimentado en lo más mínimo.

C. Reflexiones sobre el caso

El pronunciamiento de la Corte Interamericana de Derechos Humanos puede ser reconocido como excelente por la doctrina, en materia de protección y tutela efectiva de derechos fundamentales de las comunidades aborígenes, ya que su razonamiento en la resolución del caso es sumamente amplio, flexible y efectivo buscando la mejor solución posible para una minoría que ha visto conculcados drásticamente sus derechos más elementales.

Ya en 1993, la Corte había fallado en el Caso Aloeboetoe 65 y otros, en igual sentido, es decir, ordenando la realización de estudios especializados sobre la situación económica, social y cultural de estos pueblos, así como de las tradiciones, costumbres y creencias de los mismos. Es decir, la realización de estudios de tipo antropológico le permitió a la Corte en ambos casos unificar criterios en cuanto a la idiosincrasia de dichas comunidades, con la finalidad primera de dar preeminencia al derecho consuetudinario y consensuarlo luego con el derecho codificado de cada uno de los diferentes países.

Asimismo, la amplitud en sus razonamientos se ve reflejada por el reconocimiento del principio iura novit curia, al sostener que

esta Corte tiene competencia - a la luz de la Convención Americana y con base en el principio iura novit curia, el cual se encuentra sólidamente respaldado en la jurisprudencia internacional - para estudiar la posible violación de las normas de la Convención que no han sido alegadas en los escritos presentados ante ella, en la inteligencia de que las partes hayan tenido la oportunidad de expresar sus respectivas posiciones en relación con los hechos relevantes. ${ }^{66}$

De la misma forma, la Corte ha admitido el principio pacta sunt servanda por medio del cual las normas de los tratados fueron redactadas y ratificadas para ser cumplidas por los Estados miembros dentro de sus ju-

65 Caso Aloeboetoe y otros. Reparaciones, sentencia del 10 de septiembre de 1993 (artículo 63.1 CADH), serie C, núm. 15, CIDH, Secretaría, San José, Costa Rica, 1994.

66 Caso de la Comunidad Moiwana..., op. cit., nota 56, pfo. 91. 
risdicciones internas. Ellos han asumido un compromiso que, en caso de incumplir, generará responsabilidad internacional. ${ }^{67}$ Así, la Corte específicamente en este caso ha expresado que "posee especial preeminencia entre dichos principios el de pacta sunt servanda, el cual requiere que se asegure un efecto útil de las disposiciones de un tratado en el plano del derecho interno de un Estado parte". ${ }^{68}$

De esa manera, se deriva claramente del presente fallo el reconocimiento a la igualdad e inclusión de estos pueblos originarios, así como el pluralismo existente en Suriname. Por otra parte, el caso está entrecruzado por una serie de pautas de carácter más bien informales que por un formalismo rígido, lo cual hace más viable el acceso a la justicia por parte de estas comunidades.

Sin embargo, es dable preguntarnos: ¿es realmente necesario que estos pueblos tengan que esperar más de 20 años para obtener una respuesta razonable por parte de los Estados nacionales? ¿No sería más fácil que se responsabilicen de sus actos desde un primer momento? ¿No es realmente desfavorable para estos pueblos conculcarles sus derechos sin el más mínimo respeto por sus garantías judiciales? ¿Cuál es la razón por la cual colocan vallas insalvables que imposibilitan su verdadero y eficaz acceso a la justicia?

Es notoria la falta de concordancia entre la realidad de estas comunidades y el modo en que el "mundo jurídico" se les presenta. Estamos de acuerdo con que existen numerosas normas y leyes tanto nacionales como internacionales que protegen al aborigen; sin embargo, al momento de acudir a su efectiva protección, a través de resoluciones judiciales, se observa una distancia inalcanzable. Muchas veces, no sólo son víctimas de violaciones de carácter aberrante sino que con posterioridad a ello, no obtienen respuestas eficaces por parte del Poder Judicial, produciéndose de esa manera una doble victimización.

67 Convención de Viena, artículos 26 y 27.

68 Caso de la Comunidad Moiwana..., op. cit., párrafo 167. 


\section{ANÁLISIS DE LA JURISPRUDENCIA DE LOS TRIBUNALES} ARGENTINOS

\section{Jurisprudencia de la Corte Suprema de Justicia de la Nación Argentina}

Recurso de hecho deducido por la Comunidad Indígena del Pueblo Wichi Hoktek T'Oi en la causa Co Ind del Pueblo Wichi Hoktek T'Oi c/ Secretaría de Medio Ambiente y Desarrollo Sustentable, Buenos Aires, Corte Suprema de Justicia, 11 de julio de 2002.

En el caso preciso, la Secretaría Provincial de Medio Ambiente y Desarrollo Sustentable de la Provincia de Salta, en ejercicio de sus facultades administrativas, autorizó en 1996 la deforestación indiscriminada de los Catastros Rurales del Departamento San Martín sobre una superficie de 120 hectáreas, ante lo cual, la Comunidad Indígena del Pueblo Wichi Hoktek T'Oi, reconocida tribu de la provincia de Salta, intentó se dejaran sin efecto por vía judicial ordinaria tales actos administrativos, por considerarse abusivos, plenamente agraviantes al medio ambiente y a la integridad y derecho sobre el territorio que actualmente está siendo ocupado por la mencionada comunidad indígena. Ante ello, y su consecuente negativa se promovió una acción de amparo, la cual también fue rechazada. Ante las frecuentadas negativas por parte de los órganos judiciales de la provincia, se optó por interponer un recurso extraordinario ante la Corte Suprema de Justicia de la Nación, quien luego de un análisis determinó revisar nuevamente las sentencias de los tribunales, anulándolas como actos jurisdiccionales válidos y dio lugar a la acción tutelada por el artículo 43 de nuestra Constitución Nacional.

Los motivos fundantes de tal decisión no sólo se encontraron en la irregularidad misma con que fue desestimada la acción ni tampoco en las improcedentes justificaciones prestadas por los tribunales ordinarios de la provincia que constituirían propiamente una palmaria y directa afectación al derecho objetivo del debido proceso, sino que con un criterio más amplio y una perspectiva inmiscuida en el conflicto mismo, la CSJN prestó a través de su decisión apoyo directo a esta comunidad, en un tema que considera fundamental para el cumplimiento de las normas de nuestra carta suprema. 
Asimismo, es dable destacar la importancia del medio ambiente como hábitat natural de nuestros indígenas, medio de desarrollo y sustentación al que se debe resguardar, y que encuentra su cauce en nuestra carta magna y como valor de nuestra propia cultura.

Pero lo más preocupante es la incoherencia e incongruencia con la que nuestros dirigentes políticos, gobernantes y mandatarios actúan. Es inconcebible una trasgresión a nuestras normas y tratados de protección aborigen y del medio ambiente como la de este tipo. Esto pone en evidencia no sólo los agravios permanentes a estas minorías, sino también la inoperancia de las normas que velan por su protección. ${ }^{69}$

Un Estado que en la práctica viola sistemáticamente los derechos que reconoce normativamente, es un país que no transmite garantías ni respeto por sus soberanos. ¿Cuál es el camino y la solución cuando los que deben brindarla se esconden protegidos tras esferas de poderes políticos e intereses económicos?

La administración y gestión por parte de los gobiernos de provincias no debe nunca contrariar las garantías y derechos tutelados por nuestro ordenamiento, como tampoco deben hacer primar valores económicos o progresistas en detrimento de derechos más importantes y que se refieren de forma inmediata a personas que no cuentan con una alta cantidad de recursos y medios para hacer valer sus derechos, como son los indígenas hoy en nuestro Estado.

El problema no son nuestras leyes, no son nuestros legisladores, no son los tratados de carácter internacional a los cuales adherimos, ninguno de ellos muestra la oscura realidad, sino más bien una hipocresía que lejos de verse al descubierto, expande sus raíces hasta el punto de dejar desprotegidos derechos que en principio están garantizados. ¿Cuál es la operatividad y concreción de tan bellos ideales plasmados en ríos de tinta

69 Constitución Nacional Argentina, Constitución de la Provincia de Salta, Ley 7070 de Medio Ambiente de la Provincia de Salta, Ley 7107 de Áreas Protegidas de la Provincia de Salta, Ley 25.675 denominada Ley General de Ambiente o de Presupuestos Mínimos, Ley de Defensa de la Riqueza Forestal Núm. 13.273, Ley 22.421 de Protección de Fauna Silvestre, Ley 24.375 de Aprobación del Convenio sobre la Diversidad Biológica, Ley 24.701 de Aprobación de la Convención de las Naciones Unidas de Lucha Contra la Desertificación en los Países afectados por Sequía Grave o Desertificación, Ley 22.344. Aprueba la Convención Internacional sobre Especies Amenazadas de Flora y Fauna Silvestre, Convención Internacional para el Tráfico de Especies Silvestres (CITES), Tratado de Asunción, República de Paraguay fundacional del Mercosur. 
y títulos protocolares? La misión primera es la de nuestros órganos judiciales, actores estelares de este proceso de concreción y aplicación de leyes. La imparcialidad no debe de ser sólo un fin, sino más bien un medio, un instrumento para la evaluación y decisión en cada caso.

Pero cuando la solución, lejos de estar próxima en nuestro sistema, se desvanece en un cúmulo de intereses que priman por sobre derechos fundamentales que hacen a nuestra integridad, la respuesta debe buscarse por fuera: países que no cumplan con sus garantías y no respeten sus valores fundantes deben ser penados y condenados a su cumplimiento coactivo. Los derechos humanos no conocen de fronteras y tampoco deben saber de límites, su protección debe procurarse por cualquier medio y bajo cualquier circunstancia. La condición humana es previa a cualquier organización institucional política, y que esta misma debe obedecer a sus necesidades, y a la inversa... la justicia es porque los hombres son y deben...

\section{Jurisprudencia de los restantes tribunales argentinos}

Comunidad Mapuche Lonco Purran c/Provincia del Neuquén S/ Acción de Amparo, Tribunal Superior de Justicia de Neuquén, 22 de noviembre de 2005.

A continuación procederemos a realizar un relato sucinto de los hechos del presente fallo para luego referirnos a la doctrina sentada por este Tribunal Superior en uno de los casos que involucra a esta comunidad aborigen considerada hoy una de las más importantes de la República Argentina, la cual tiene su principal asentamiento en el sur del país. Esta comunidad ha despertado el interés de numerosos estudiosos con el fin de aportar a la lucha y defensa de estos pueblos originarios y convertirse así en una herramienta fundamental para el análisis jurídico e histórico con rigor documental. ${ }^{70}$

La actora interpuso recurso de casación por inaplicabilidad de la ley contra el decisorio dictado por la Cámara de Apelaciones en lo Civil, Comercial, Laboral y de Minería. Los hechos versan sobre la pretensión ad-

70 Hualpa, Eduardo Raúl, "Sin despojos. Derecho a la participación mapuche-tehuelche", Cuadernos de ENEPA, Chubut, núm. 4, 2003. 
ministrativa exteriorizada mediante Ley Provincial Número 77 de encuadrar la organización indígena en las normas de las asociaciones civiles, lo que según el argumento sostenido violenta notablemente el artículo 75 inciso 17 de nuestra Constitución Nacional.

Las premisas ideológicas bajo las cuales se elaboró este nuevo artículo han sido bastantes distintas a la matriz tenida en cuenta por el constituyente originario, respondiendo a una nueva óptica del constitucionalismo acerca de las minorías, de la igualdad y la diferencia. Es el reflejo del principio personalista que considera la caracterización colectiva e histórica de la persona, su inclusión en un grupo social más amplio y dotado de una destacada individualidad ${ }^{71}$ y el artículo 14 del Convenio 169 de la OIT. ${ }^{72}$

Al no existir norma provincial, ley, decreto o reglamento que regulen la efectivización del derecho de propiedad de las tierras por parte de estos pueblos indígenas, se sostiene que no existe una vía ordinaria para imponer a la administración la aceptación de la personalidad de la comunidad reconocida asimismo por la Ley Nacional número $23.302,{ }^{73}$ en donde se declaró de interés nacional la atención y el apoyo a los aborígenes y a las comunidades indígenas existentes en el país, así como su defensa y desarrollo para su plena participación en el proceso socioeconómico y cultural de la nación, respetando sus propios valores y modalidades, por

71 Carnota, Walter, "Iguales pero distintos. Los indígenas de cara a la Constitución Nacional", Constitución de la Nación Argentina, Santa Fe, Asociación Argentina de Derecho Constitucional, 2003, t. I, pp. 238 y 239.

72 Aclárase al lector: artículo 14, Convenio OIT, parte pertinente, apartado 2: "Los gobiernos deberán las medidas que sean necesarias para determinar las tierras que los pueblos ocupan tradicionalmente y garantizar la protección efectiva de sus derechos de propiedad y posesión".

73 B. O. del 12 de noviembre de 1985, crea también el Instituto Nacional de Asuntos Indígenas. Debieron transcurrir más de tres años para que dicha normativa fuera reglamentada, lo que se concretó por medio del Decreto Nacional 155/89, B. O. del 17 de febrero de 1989. 
ejemplo el derecho a la propiedad de las tierras, ${ }^{74}$ el correspondiente a su lengua, ${ }^{75}$ etcétera. ${ }^{76}$

Con lo anteriormente expuesto queda en evidencia la no existencia de otra vía que resulte idónea para la protección de los derechos invocados; ${ }^{77}$ único requisito que condiciona la admisibilidad de la acción de amparo desde la reforma constitucional efectuada en 1994.

Este Tribunal considera que por no haber mediado invocación y demostración de un agravio de imposible o dificultosa reparación posterior, o la configuración de gravedad institucional, la recurrente no ha enderezado su planteo a la plena y cabal demostración de sus aciertos, por lo cual no podría basarse en la excepcional apertura de la instancia aquí intentada en la mera alegación que el procedimiento ordinario no resulta eficaz. Aduce que la doctrina sentada por el mismo Tribunal Superior de Justicia en anteriores resoluciones ${ }^{78}$ autoriza a superar los escollos formales prescritos por la Ley Procesal Provincial reglamentaria de los recursos extraordinarios locales. Ésta sólo sería aplicable si los recurrentes hubiesen realizado un planteo concreto y serio de la cuestión federal que entienden suscitada en la causa, extremo que luce ausente en la misma.

Por lo expuesto, se impuso la declaración de inadmisibilidad del remedio procesal incoado, deviniendo abstracto el tratamiento de los restantes

74 Fernández, Edgardo R. s/usurpación, Juzgado de Instrucción núm. II de San Carlos de Bariloche, 21 de abril de 2004.

75 Albarracín, Lelia Inés, "Multiculturalidad y plurilingüismo: el derecho al uso de la propia lengua", VI Jornadas Internacionales de Educación: Complejidad, Rupturas y Desafios, Ciudad de Concordia, Facultad de Ciencias de la Administración, Universidad Nacional de Entre Ríos, del 4 al 6 de septiembre de 2003.

76 Bazán, Vìctor, "De indios a pueblos indígenas; de la asimilación al pluralismo cultural", Constitución de la Nación Argentina, Santa Fe, Asociación Argentina de Derecho Constitucional, 2003, t. I, p. 181.

77 Artículos 25 Convención Americana sobre Derechos Humanos, 43 de la Constitución Nacional y 12 del Convenio 169 de la OIT, parte pertinente de este último: "Los pueblos interesados deberán tener protección contra la violación de sus derechos, y poder iniciar procedimientos legales, sea personalmente o bien por conducto de sus organismos representativos, para asegurar el respeto efectivo de tales derechos. Deberán tomarse medidas para garantizar que los miembros de dichos pueblos puedan comprender y hacerse comprender en procedimientos legales, facilitándoles, si fuere necesario, intérpretes u otros medios eficaces".

78 CSJN, Caso Strada, Fallos 308:490, 1986; Caso Di Mascio, Fallos 311:2478, 1988. 
recaudos previstos por el ritual, y con ello también los derechos que pretendían el debido resguardo judicial. ${ }^{79}$

\section{Valoración crítica del caso}

En el presente, no vamos a avocarnos a la naturaleza del derecho que se reclama, sino al formalismo que exige este Tribunal aplicando rígidamente el derecho positivo, más específicamente la regulación procesal. Es decir, no es un conflicto entre el derecho estatal y el consuetudinario, sino que se trata de determinar hasta qué punto debe aplicarse un rigorismo formal bajo criterios no objetivos sin tomar en cuenta la esencia del reclamo que en su interior contiene derechos subjetivos reconocidos por nuestro bloque de constitucionalidad, pero que se desconocen amparándose en dicho ritual.

En esta problemática compleja, en un gran número de países existen minorías con derechos propios, los cuales funcionan informal y casi ilegalmente; pero la situación en este caso es radicalmente opuesta, ya que éstos grupos culturales no están rigiéndose en este caso por su derecho informal sino que reclaman un derecho que se encuentra inmerso en el derecho oficial, reconocimiento que les pertenece por ser tan originarios al país como aquellos otros que lo impusieron. ${ }^{80}$

Teniendo en cuenta que nuestro país en numerosas oportunidades ratificó su política de protección a los derechos y libertades fundamentales de los pueblos indígenas ya mencionados ut supra, consideramos pertinente recalcar el derecho al acceso de los diversos recursos naturales. ${ }^{81}$

Expresando su voluntad de resguardar estos derechos dentro del orden público y en cumplimiento de nuestras disposiciones constitucionales y legales vigente; no consideramos apropiado en virtud de la aplicación de un principio formal desconocer derechos y obligaciones de éstas índoles. Sin olvidar que esto de traduce en el deber de nuestros Estados de cautelar y garantizar, la aplicación de todas las disposiciones de los instrumen-

79 Las cursivas representan en este caso un adelanto a la valoración crítica de caso por el autor.

80 Urquizo Olaechea, José (dir.), Revista Peruana de Ciencias Penales, Lima, núm. 4, año II, julio-diciembre de 1994, p. 693.

81 Picolotti, Romina y Bordenave Sofía, Caso Comunidad Paynemil, "Los derechos humanos y el medio ambiente", Vega, Juan Carlos (dir.), Derechos humanos: legalidad y jurisdicción supranacional, Córdoba, Editorial Mediterránea, 2006, p. 207. 
tos de carácter internacional, con la finalidad de asegurar el ejercicio pleno de los derechos humanos de las poblaciones indígenas conforme al principio de no discriminación. ${ }^{82}$

Para finalizar, en el presente fallo observamos un incumplimiento del deber del Poder Judicial de tutelar derechos amparándose en criterios subjetivos de apreciación, lo que no compartimos ya que no permite la operativización de nuestros derechos al no encontrarse debidamente reglamentados.

En consecuencia, advertimos la necesidad de una modificación de este criterio lo que se vislumbra en jurisprudencia correspondiente de otros tribunales nacionales. ${ }^{83}$ En el presente, según nuestro humilde parecer, no se vislumbra la primacía de garantizar efectivamente derechos fundamentales lo que debería ser el eje del rol judicial. Si adoptáramos una postura diametralmente diferente implicaría sostener que al no existir los referentes teóricos entonces corresponde negar la validez y existencia real del fenómeno social que acaece. ${ }^{84}$

\section{3. "Puel, Raúl sobre Daño", Tribunal Superior de Justicia de Neuquén, del 12 de marzo de 1999}

El fallo "Puel, Raúl sobre Daño" hace referencia a un recurso de casación interpuesto en contra de la sentencia que declaró a Raúl Puel, autor penalmente responsable del delito de daño, ${ }^{85}$ imponiéndole la pena correspondiente a un mes de prisión en forma condicional.

82 Con ocasión de la toma de posesión del mandatario peruano, Alejandro Toledo, los presidentes de la Comunidad Andina de Naciones (CAN) suscribieron la Declaración de Machu Picchu sobre la Democracia, los Derechos de los Pueblos Indígenas y la Lucha contra la Pobreza, entre dichos participantes se encuentra el titular correspondiente de nuestro país, así como Brasil, Chile, Costa Rica, Panamá, Paraguay, República Dominicana, Uruguay, el Príncipe de Asturias y el secretario de la Comunidad Andina, Lima, Machu Picchu, 28 y 29 de julio de 2001.

83 Caso Sede, Alfredo y Otros c/Vila, Herminia y otro s/Desalojo, III Circunscripción Judicial de Río Negro, Juzgado de Primera Instancia en lo Civil y Comercial y Minería núm. 5, secretaría única, San Carlos de Bariloche, 12 de agosto de 2004.

84 Mato, Daniel, "Movimiento indígena ecuatoriano: construcción política y epistémica", Compilación, estudios y otras prácticas intelectuales latinoamericanas en cultura $y$ poder, CLACSO/FaCES/UCV, Caracas, marzo de 2002.

85 Aclárese al lector, artículo 183, Código Penal, "Daños": "Será reprimido con prisión de quince días a un año, el que destruyere, inutilizare, hiciere desaparecer o de cual- 
Las cuestiones de este fallo versaron acerca de la procedencia del recurso interpuesto, cuestionando la recurrente una valoración efectuada por el Tribunal a quo de la declaración de un testigo que afirmaba que el daño fue perpetrado por el condenado. Además, se critica la subsunción que realiza el tribunal inferior de la conducta de su defendido ya que no puede merecer reproche alguno el hecho de quitar estacas ilegítimamente colocadas en la propiedad de la comunidad indígena Puel, lugar donde vive el imputado con su familia.

Ello así por cuanto quienes realizaron las obras de marcación, las cuales resultaron dañadas, realizó las mismas penetrando al terreno ajeno sin autorización y apropiándose además de un canal realizado personalmente por el Sr. Puel, el cual luego sería cercado provocando la exclusión del mismo sin ninguna servidumbre de paso constituida, ni autorización requerida a los fines de satisfacer la necesidad de la mentada Comisión de Fomento para sus residencias de verano. ${ }^{86}$

A las cuestiones aducidas, el Tribunal resuelve declarando procedente el recurso interpuesto pero expresando las siguientes salvedades: tratándose de la primera cuestión introducida, respecto a la valoración de la prueba, ratifica la soberanía del órgano jurisdiccional en cuanto al análisis crítico de los elementos de prueba legalmente incorporados, no pudiendo el Tribunal de Casación cuestionar el juicio de mérito sobre la selección y valoración. ${ }^{87}$

Y por último refiriéndose a la segunda y última cuestión introducida, valida el razonamiento realizado por la Señora Defensora en cuanto a la errónea aplicación de la ley penal, pero considerándolo correcto sólo parcialmente manteniendo la clasificación ilícita de la conducta efectuada pero estimando que ha mediado a favor del imputado una causa de justificación putativa. ${ }^{88}$

quier modo dañare una cosa mueble o inmueble o un animal, total o parcialmente ajeno, siempre que el hecho no constituya otro delito más severamente penado".

86 Tribunal Superior de Justicia de Neuquén, "Puel, Raúl sobre Daño, del 12 de marzo de 1999", publicado en www.bioetica.org.com.

87 Rúa, Fernando de la, "La casación penal", Buenos Aires, Depalma, 1994, p. 140.

88 Aclárese al lector: en virtud del artículo 34 incs. 1 y 6 del Código Penal; parte pertinente, no son punibles: 1) El que no haya podido al momento del hecho, ya sea por insuficiencia de sus facultades, por alteraciones morbosas de las mismas o por su estado 


\section{Valoración crítica del caso}

Como consecuencia de nuestro nuevo marco constitucional, artículo 75 inciso $17 \mathrm{y}$, a su vez, artículo 27 del Pacto Internacional, debe garantizarse a las comunidades étnicas que habitan el territorio nacional la posibilidad de "integrarse con sus diferencias, en la igualdad de sus perfiles; en otras palabras respeto a su identidad es equivalente a tratamiento igualitario sin pérdida ni renuncia de su identidad". ${ }^{89}$

Esto implica que ciertas conductas desplegadas en el ámbito de determinados grupos étnicos deben ser analizadas en función del significado que las mismas adquieren dentro de su atmósfera cultural; ello, simplemente porque es dentro de esa atmósfera en que se vuelven inteligibles. ${ }^{90}$

Surge la necesidad de reflexionar seriamente acerca del respeto de las diferencias y de las consecuencias prácticas que se derivan, para el ordenamiento vigente y órganos de aplicación, de considerar que coexisten, dentro de los límites de un mismo Estado, sistemas de regulación social claramente diversos. En el presente fallo se observa el intento por homogeneizar dicho pluralismo para hacer posible la aplicación amena del derecho positivo. ${ }^{91}$

Dado que las demandas indígenas se han enfatizado al igual que los reclamos específicos de las comunidades con relación a la obtención de territorios, al desarrollo étnico y cultural, entre otros, es que se justifica la necesidad de la existencia de los niveles de coordinación entre los diferentes sistemas jurídicos. Este sistema se encuentra en dos niveles que se distinguen nítidamente; uno normativo en el cual la pluralidad jurídica está reconocida constitucionalmente en diferentes países latinoamerica-

de inconciencia, error o ignorancia de hecho no imputable, comprender la criminalidad del acto o dirigir sus acciones. 6) El que obrare en defensa propia o de sus derechos, siempre que concurrieren las siguientes circunstancias: a) agresión ilegítima; b) necesidad racional del medio empleado para impedirla o repelerla; c) falta de provocación suficiente por parte del que se defiende...

89 Bidart Campos, Germán, Tratado elemental de derecho constitucional argentino, Buenos Aires, Ediar, 1995, t. IV, p. 373.

90 Kalinsky, Beatriz, Diversidad sociocultural y formas punitivas del Estado. En busca de respuestas antropológicas al sistema jurídico penal en el sur de la Provincia del Neuquén, Argentina, Alteridades, 1996, p. 92.

91 Ramírez, Silvina, “ Diversidad cultural y sistema penal: necesidad de un abordaje multidisciplinario, pena y Estado, justicia penal y comunidades indígenas”, Revista Latinoamericana de Política Criminal, Buenos Aires, año 4, núm. 4, 2000, p. 65. 
nos, mientras que el otro es un nivel fáctico en donde se reconoce la existencia de diversidad aceptando los derechos reclamados por los pueblos indígenas. La diferencia entre el derecho indígena y el derecho positivo estriba en el diferente tratamiento al infractor, lo cual se vislumbra claramente en este caso donde se intenta congeniar el derecho consuetudinario y con él todas sus particularidades para encuadrar la figura dentro de una causal de justificación. De este modo, consideramos meritoria la tarea del Poder Judicial en su fin de lograr el efectivo resguardo de los derechos de estas comunidades.

Esta tarea no se considera sencilla, ya que las leyes reglamentarias no han avanzado para viabilizar los grandes principios constitucionales, lo que facilitaría la evolución de distintos conceptos que no consideren punibles los procedimientos, los mecanismos y las medidas de resolución de conflictos, así como los mecanismos coercitivos y sanciones que se den en el marco de la justicia indígena (con el límite de no violar derechos humanos).

El Estado y sus agencias deben abstenerse de una intervención punitiva cuando los hechos se fundan en la cultura y prácticas jurídicas indígenas. Esto debe explicitarse en normas de desarrollo constitucional, en una ley específica de coordinación y/o en los respectivos códigos Penal y Procesal Penal. Un caso en este sentido es el código Penal Peruano de 1991 que despenaliza la comisión de hechos punibles cuando están basados en la cultura o costumbres (artículo 15). ${ }^{92}$

En consonancia con lo expuesto, consideramos dable mencionar que en este precedente el Tribunal no aplicó el derecho indígena reconociéndolo ampliamente, pero lo morigeró para lograr la tan pretendida adaptación entre ambos sistemas.

4. Comunidad Mapuche Catalán y Confederación Indígena Neuquina c/

Provincia de Neuquén s/Acción de Inconstitucionalidad, Tribunal

Superior de Justicia de la Provincia de Neuquén, 3 de junio de 2004

A través del análisis de esta nueva porción de la realidad, abordaremos el rol del Poder Judicial, con respecto a la tutela de derechos humanos

92 Yrigoyen Fajardo, Raquel, Pautas para el reconocimiento constitucional del derecho indígena y su coordinación con el derecho estatal, Guatemala, Fundación Myrna Mack, 1999, cap. 2. 
que se ven comprometidos ante la asimilación coactiva a una ideología la cual dirige un programa de valores, sacrificios y renuncias correspondientes, lo que nos parece perfectamente razonable pero que debe ser capaz de regular la sustitución de dicho programa, dando seguridades de que se logrará el consenso de quienes se vean obligados a demorar sus propios valores. ${ }^{93}$

Los accionantes, en el marco de la acción regulada en la que pretenden la declaración de inconstitucionalidad de la Ley 2439 y del decreto núm. 002/04, requieren una medida de carácter cautelar para que el Tribunal Superior disponga la suspensión del acto eleccionario a realizarse el 6 de junio de 2004.

El fundamento de su requerimiento está dado en que, de llevarse a cabo el acto electoral convocado a efectos de que la comunidad exprese su voto para seleccionar a las autoridades que conformarán la Comisión Municipal de Villa Pehuenia, se obligaría a los miembros de las comunidades indígenas que representan, a participar bajo pena de ser sancionados en una actividad que consideran dañina para la preservación de su propia cultura.

El Tribunal recalca que la medida solicitada reviste un carácter excepcional en el marco de la acción de inconstitucionalidad, ${ }^{44}$ por la indudable presunción de validez que poseen los actos de los poderes públicos y porque tal petición implica indirectamente, la suspensión de la aplicación de actos de alcance general que prima facie, se hallan investidos de la misma, ${ }^{95}$ y que concomitantemente con el derecho fundamental invocado, los constituyentes han establecido obligaciones que pesan sobre los poderes constituidos y sobre los habitantes de la nación.

\section{Valoración crítica del caso}

En el presente caso, atento al marcado cariz restrictivo que adopta el Tribunal Superior para ponderar este tipo de peticiones precautorias, se impuso el rechazo del requerimiento cautelar sub examine, aduciendo que los argumentos actorales no alcanzaban para enervar la acción.

93 Revista Mexicana de Justicia, vol. V, núm. 4, octubre-diciembre, México, 1987.

94 Arias Jorge Meliton c/Comisión Municipal de El Huecu s/acción de inconstitucionalidad, Neuquén, Tribunal Superior de Justicia de Neuquén, 1o. de julio de 2005.

95 Al respecto se encontraron numerosos antecedentes de este Tribunal Superior de Justicia plasmados en R. I., núms. 1146/94, 1150/94, 1328/96, entre otros. 
Pese a ello consideramos que aquí lo que se vislumbra es un caso de asimilación coactiva y el no reconocimiento al pluriculturalismo que tanto enarbolamos. No se toma en cuenta que las normas reguladoras de la sociedad envolvente están fundamentadas sobre presupuestos culturales, axiomas distintos, escalas valorativas diferentes a la de las sociedades indígenas. ${ }^{96}$

Ya no es suficiente una normativa sobre la base de órdenes, la conducta tiende a conformarse paulatinamente en torno a la calidad de proyecto colectivo por el carácter de las normas sobre las cuales se edifica, pese a no negar la necesariedad de un ámbito común y de conexión para un ordenado convivir. Creemos que el juicio de valor aparece necesario toda vez que se quiere justificar, explicar o inspirar el comportamiento ético de una sociedad y de los miembros que la integran.

Habida cuenta de los impedimentos sociales que existían en el caso analizado (por tratarse de un acto del ejercicio de la soberanía popular y a su vez un deber cívico), sostenemos que se debería haber brindado una protección diferente, didáctica que permita crear nuevos horizontes a las necesidades de los indígenas y no asimilar coactivamente a éstos a un sistema que resulta propenso a caer en la clasificación de falacia natural, ya que no se adoptó una posición racional y conciliadora, lo que constituye una actitud fundamental que debe adoptar la clase dirigente. ${ }^{97}$

En "materia aborigen" ante la escasez de reglamentación y ante la reiteración de un vacío crítico por parte de la legislación; la interpretación jurisprudencial aplicada con conciencia y respeto por la diversidad cultural existente, se torna la única herramienta para desalojar la dimensión utópica que se tiene del respeto de estas comunidades.

96 Chase Miguel-Sardi, Augusto y Brun Miguel Ángel Enciso, Hacia una tesis jurídica de la antropología social del apoyo en el Paraguay, Asunción, Centro Interdisciplinario de Derecho Social y Economía Política, Universidad Católica Nuestra Señora de la Asunción, 1990, p. 33.

97 Elizalde H., Antonio, Las nuevas utopias de la diversidad, lo deseable vuelve a ser posible, Santiago de Chile, Polis, Editorial Universidad Bolivariana, vol. II, núm. 6, 2003, p. 523. 


\section{REFLEXIONES FINALES}

Del análisis realizado advertimos un contraste entre los pronunciamientos de la CIDH y los fallos de los tribunales argentinos.

De un lado, en las sentencias contenciosas de la CIDH se han adoptado criterios de inclusión de los aborígenes, mediante la flexibilización, tanto de las reglas procesales como del orden jurídico aplicado para la solución del caso, mediante la armonización del derecho positivo nacional de los Estados con el derecho consuetudinario de las comunidades aborígenes.

Resulta destacable además la amplitud de las dimensiones tenidas en cuenta por la CIDH al momento de fundar sus resoluciones. Así, sus sentencias han considerado cuestiones no sólo jurídicas, sino también sociológicas, antropológicas, históricas y culturales, lo que demuestra un enfoque integral que permite lograr una resolución ajustada al caso concreto.

Por otra parte, la jurisprudencia nacional sobre la materia presenta un panorama heterogéneo, por cuanto, si bien se observan algunos precedentes que - bajo criterios rigoristas y formalistas - han disipado el acceso a la justicia de los aborígenes, con un evidente resultado de exclusión; no es menos cierto que en otras oportunidades los tribunales han demostrado un interesante activismo generando respuestas - ajustadas y receptivas de la cosmovisión aborigen-, mediante una interpretación ágil y flexible del derecho positivo nacional.

De igual modo, son dignas de elogio algunas medidas probatorias adoptadas por nuestros tribunales a los efectos de tomar conocimiento de visu del contexto físico de los hechos invocados en el litigio, abundando de este modo el decisorio judicial con vivencias de la propia realidad aborigen.

En la esfera jurisdiccional supranacional, observamos que el derecho al acceso a la justicia de los miembros de estas comunidades no es habitualmente respetado por los Estados latinoamericanos, al tiempo que los tribunales argentinos no siempre han sido lo suficientemente flexibles en la interpretación de las formas y reglas procesales para habilitarles el acceso a la jurisdicción.

Además del referido derecho, entre los otros derechos que más frecuentemente han sido violados determinando la intervención de la $\mathrm{CIDH}$, se destacan el derecho a la vida, a la integridad personal, a la libre circu- 
lación, a la propiedad de sus tierras y, en menor medida, los derechos políticos y a la identidad cultural de los aborígenes. En la jurisprudencia nacional, se han destacado frecuentemente el derecho a la propiedad comunitaria de sus tierras, así como el respeto a su medio ambiente y hábitat, y - en menor medida - el derecho a su identidad cultural. En general, tanto en la esfera nacional como supranacional, los actos que han lesionado estos derechos han sido ejecutados por el propio Estado.

Con respecto a la determinación de los límites al acogimiento del derecho consuetudinario aborigen, la CIDH ha consolidado en sus sentencias una doctrina sólida y coherente, destacando que tales costumbres no pueden atentar contra los restantes derechos consagrados por la $\mathrm{CADH}$, al tiempo que los tribunales argentinos no se han explayado sobre tal aspecto, por cuanto - en general - sus soluciones han pretendido partir de una armonización del derecho nacional, antes que de un acogimiento del derecho consuetudinario aborigen.

Respecto del carácter asignado al colectivo aborigen, la jurisprudencia de la CIDH les ha deparado un tratamiento como comunidades, antes que como minorías, sin que en la jurisprudencia nacional se advierta una distinción de significación o relevante al respecto, toda vez que tal cuestión no ha sido abordada.

En cuanto al paradigma social subyacente en la jurisprudencia analizada, las sentencias de la CIDH responden a un modelo multiétnico y pluricultural, siendo que los fallos de los tribunales argentinos son heterogéneos, aunque se advierte cierta subsistencia del modelo de homogeneidad, tal vez como resabio del paradigma imperante en el viejo texto del artículo 67, inc. 15 de la Constitución Nacional.

No hemos identificado en los fallos analizados de los tribunales argentinos actos o prácticas discriminatorios en al acceso a la jurisdicción, como tampoco en las sentencias de la $\mathrm{CIDH}$, aunque estas últimas sí darían cuenta de ciertas prácticas restrictivas en otros Estados latinoamericanos.

Pese a la heterogeneidad observada, creemos que las pautas sentadas normativa y doctrinariamente constituyen un primer paso en miras a lograr la plena vigencia de los derechos jurídicamente reconocidos. Pero ello no es suficiente. Es necesario continuar el tránsito para el logro de tal cometido. 
Las comunidades indígenas gozan de derechos reconocidos a nivel internacional y, en la mayoría de los países latinoamericanos, a nivel constitucional e infralegal. Pero el conflicto no reside en la falta de normas que garanticen sus derechos, sino en la falta de obediencia de los mandatos que dicha normativa dirige a nuestra sociedad. Un Estado que preconiza sólo de palabra inmensas garantías y derechos, sin esforzarse en su vigencia sociológica es un Estado que no protege adecuadamente a sus soberanos.

El objetivo es lograr la tutela judicial efectiva que nos permita superar lo formal (la palabra) y pasar a lo real (acción); para que "la acción responda a la palabra y la palabra a la acción"; 98 buscar la justicia, hoy, para el indígena y su comunidad, quiere decir que aquella igualdad, antes sólo formal, sólo en la palabra de la ley, sea transformada en una igualdad material, que respete sus características culturales propias.

En este camino que se está transitando, revista una importancia insoslayable, el rol del juez, ya que son los magistrados quienes se encuentran en mejores condiciones de indagar en la búsqueda de criterios que lleven a una armonización del derecho positivo con la costumbre jurídica de las diversas comunidades aborígenes, a los fines de una tutela efectiva de sus derechos fundamentales. En consonancia con ello, puede afirmarse que se exige que los magistrados adquieran un rol "activista", es decir, una actitud innovadora, progresista y evolutiva al momento de pronunciarse en sus sentencias o fallos para así lograr el reconocimiento y protección de los tan mentados derechos indígenas, reconocidos tanto a nivel nacional como internacional. Bien ha señalado Piero Calamandrei que

el juez tiene, efectivamente, como el mago de la fábula, el sobrehumano poder de producir en el mundo del derecho las más monstruosas metamorfosis, y de dar a las sombras apariencias eternas de verdades; y porque, dentro de su mundo, sentencia y verdad deben en definitiva coincidir, puede, si la sentencia no se adapta a la verdad reducir la verdad a la medida de su sentencia. ${ }^{99}$

98 Shakespeare, William, Hamlet, acto tercero, escena VIII (el Príncipe de Dinamarca les aconseja sobre cómo representar su obra - en virtud del crimen que habían cometido a su padre- a los comediantes 1, 2, 3 y 4).

99 Calamandrei, Piero, El elogio de los jueces, escrito por un abogado, Buenos Aires, Librería El Foro, 1997, p. 69. 
Actualmente, se transita hacia el perfeccionamiento de la labor del Poder Judicial a través de sus sentencias, y aunque el camino a recorrer sea largo confiamos en que estamos acercando las usualmente lejanas brechas que separan la exhuberancia fraseológica del cumplimiento efectivo de las promesas normativas, transformándolas en conductas perceptibles y realizaciones concretas. Creemos que el Poder Judicial está tomando conciencia que la importancia de la problemática aborigen exige mucho más que meras evocaciones alegóricas.

El rol del Estado en la situación de los indígenas resulta esencial. Y, lamentablemente, no lo ha cumplido de la mejor manera hasta aquí, ya que, por un lado, la mayoría de las vulneraciones más gravosas a los derechos de comunidades aborígenes proceden del accionar del propio Estado - afectando principalmente su derecho a su propia identidad cultural y a la posesión y propiedad comunitarias de sus tierras-; por otro lado, los órganos jurisdiccionales estatales - que debieran ser los garantes del efectivo cumplimiento de los derechos constitucionalmente reconocidos- en ocasiones se apartan de la normativa vigente, en perjuicio de estos grupos minoritarios.

\section{BIBLIOGRAFÍA}

ALBARRACÍN, Lelia Inés, "Multiculturalidad y plurilingüismo: el derecho al uso de la propia lengua", ponencia presentada en las VI Jornadas Internacionales de Educación: Complejidad, Rupturas y Desafíos, Ciudad de Concordia, Universidad Nacional de Entre Ríos, Facultad de Ciencias de la Administración, del 4 al 6 de septiembre de 2003.

BARALE, Laura et al., "Las comunidades indígenas en la Reforma Constitucional del 1994. Del principio de identidad a las circunstancias de justicia”, Semanario Jurídico. Fallos y Doctrina, Córdoba, núm. 1324, 11 de enero de 2001.

BAZÁN, Víctor, "De indios a pueblos indígenas; de la asimilación al pluralismo cultural", Constitución de la Nación Argentina, Santa Fe, Asociación Argentina de Derecho Constitucional, 2003, t. I.

BECERRA FERRER, Guillermo et al., Manual de derecho constitucional, 2a. ed., Córdoba, Advocatus, 1999, t. I.

BIDART CAMPOS, Germán, "Los derechos de los pueblos indígenas argentinos", La Ley 1996-B, 1205. 
, Manual de la Constitución reformada, Buenos Aires, Ediar, 1999, t. III.

- Tratado elemental de derecho constitucional argentino, Buenos Aires, Ediar, 1995, t. IV.

BIDEgain, Carlos María, Curso de derecho constitucional, Buenos Aires, Abeledo Perrot, 1995, t. II.

CANET, Viviana, "Institucionalización de las prácticas de los pueblos y comunidades indígenas en la Argentina", Suplemento de Derecho Administrativo, Jurisprudencia Argentina, Buenos Aires, Lexis Nexis, 2005.

CARNOTA, Walter, "Iguales pero distintos. Los indígenas de cara a la Constitución Nacional", Constitución de la Nación Argentina, Santa Fe, Asociación Argentina de Derecho Constitucional, 2003, t. I.

Picolotti, Romina y Bordenave, Sofía, "Caso Comunidad Paynemil", Los derechos humanos y el medio ambiente. Derechos humanos: legalidad y jurisdicción supranacional, Córdoba, Mediterránea, 2006.

CHASE, Miguel et al., Hacia una tesis jurídica de la antropología social del apoyo en el Paraguay, Asunción, Centro Interdisciplinario de Derecho Social y Economía Política, Universidad Católica Nuestra Señora de la Asunción, marzo de 1990.

EKMEKDJiAn, Miguel Ángel, Tratado de derecho constitucional, Buenos Aires, Depalma, 1997-1999, 5 vols.

ELIZALDE H., Antonio, "Las nuevas utopías de la diversidad, lo deseable vuelve a ser posible", Polis, Santiago de Chile, vol. II, núm. 6, 2003.

Gelli, María A., Constitución de la Nación Argentina, 2a. ed., Buenos Aires, La Ley, 2003.

GHERSI, Carlos, "Comentario al fallo C. Civ. y Com. Jujuy, sala primera, 14/9/2001. «Comunidad aborigen de Quera y Aguas Calientes - Pueblo Cochinoca vs. Provincia de Jujuy»", Jurisprudencia Argentina, 2002III-702.

HITTERS, Juan Carlos, "La jurisprudencia de la Corte Interamericana como guía para la interpretación de la Constitución (El Pacto de San José de Costa Rica, en la postura de la Corte Suprema Nacional)", El Derecho, 1995, t. 164.

HuALPA, Eduardo Raúl, "Sin despojos. Derecho a la participación Mapuche-Tehuelche", Cuadernos de ENEPA, Chubut, núm. 4, 2003.

KALINSKY, Beatriz, Diversidad sociocultural y formas punitivas del Estado. En busca de respuestas antropológicas al sistema jurídico penal en 
el sur de la Provincia del Neuquén, Argentina, Editorial Alteridades, 1996.

MATO, Daniel (comp.), "Movimiento indígena ecuatoriano: construcción política y epistémica", Estudios y otras prácticas intelectuales latinoamericanas en cultura y poder, CLACSO/ FaCES/UCV, Caracas, marzo de 2002.

POLlitzer, Germán A., Marco legal para las comunidades indígenas de Argentina, Fundación Cruzada Patagónica, 2001.

RAMÍREZ, Silvina, "Diversidad cultural y sistema penal: necesidad de un abordaje multidisciplinario", Pena y Estado. Justicia Penal y Comunidades Indígenas. Revista Latinoamericana de Política Criminal, Buenos Aires, año 4, núm. 4, 2000.

, "Diversidad y derechos humanos. Un desafío para la administración de justicia penal", Revista Aportes Andinos, Ecuador, núm. 11, octubre de 2004.

Revista Mexicana de Justicia, México, vol. V, núm. 4, octubre-diciembre de 1987.

Revista Peruana de Ciencias Penales, Lima, año II, núm. 4, julio-diciembre de 1994.

RIVERA, José Antonio, "Los pueblos indígenas y las comunidades campesinas en el sistema constitucional boliviano", Anuario 2005 de Derecho Constitucional Latinoamericano, Montevideo, año 11, 2005.

RosATTI, Horacio D., La reforma de la Constitución, Buenos Aires, 2002.

—, "Status constitucional de los pueblos indígenas argentinos", La Reforma de la Constitución, Santa Fe, Rubinzal Culzoni, 1994.

RÚA, Fernando de la, La casación penal, Buenos Aires, Depalma, 1994.

YRIGOYEN FAJARDO, Raquel, Pautas para el reconocimiento constitucional del derecho indígena y su coordinación con el derecho estatal, Guatemala, Fundación Myrna Mack.

ZAFFARONI, Eugenio Raúl, Estructuras judiciales, Buenos Aires, Ediar, 1994.

Sitios en Internet

http://www.corteidh.or.cr

http://www.indigenas.bioetica.org

http://www.cciseta.com 
http://www.bioetica.org

http://www.ecoportal.net

http://www.aborigenargentino.com.ar

http://www.galaxio.com

http://www.tierraviva.org.py/reivindica.htm 